Portland State University

PDXScholar

1989

\title{
Staff Development and the Process of Teacher Change: A Case Study
}

Christene Kay Jones

Portland State University

Follow this and additional works at: https://pdxscholar.library.pdx.edu/open_access_etds

Part of the Educational Leadership Commons, Elementary Education and Teaching Commons, and the Other Teacher Education and Professional Development Commons

Let us know how access to this document benefits you.

\section{Recommended Citation}

Jones, Christene Kay, "Staff Development and the Process of Teacher Change: A Case Study" (1989). Dissertations and Theses. Paper 1258.

https://doi.org/10.15760/etd.1257

This Dissertation is brought to you for free and open access. It has been accepted for inclusion in Dissertations and Theses by an authorized administrator of PDXScholar. Please contact us if we can make this document more accessible: pdxscholar@pdx.edu. 
STAFF DEVELOPMENT AND THE PROCESS

OF TEACHER CHANGE: A CASE STUDY

By

CHRISTENE KAY JONES

A dissertation submitted in partial fulfillment of the requirements for the degree of

DOCTOR OF EDUCATION

in

EDUCATIONAL LEADERSHIP :

EDUCATIONAL ADMINISTRATION AND SUPERVISION

Portland State University

C1 989 


\section{TO THE OFFICE OF GRADUATE STUDIES:}

The members of the Committee approve the

dissertation of Christene Kay Jones presented May 5, 1989.

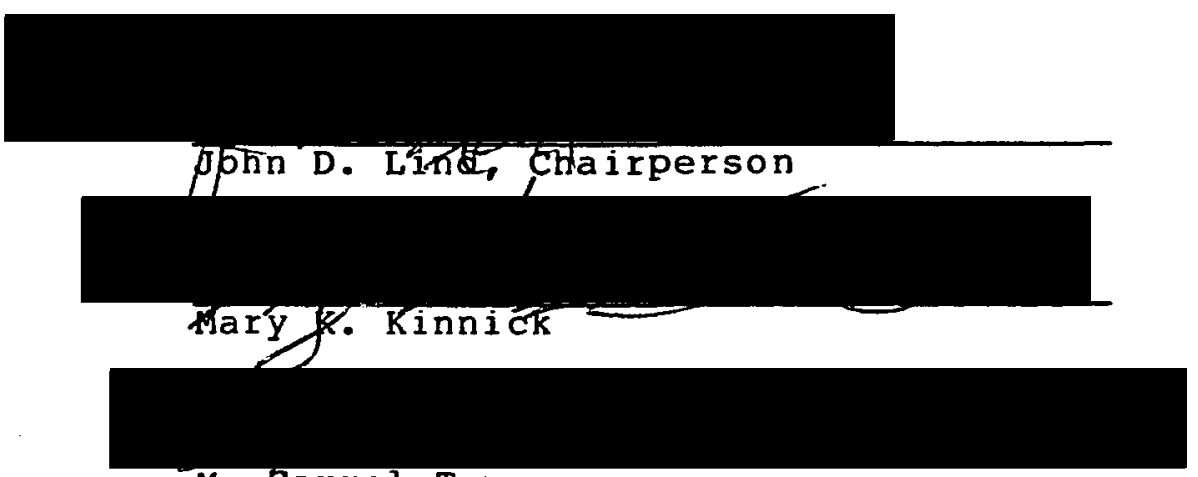

M. Carrol Tama

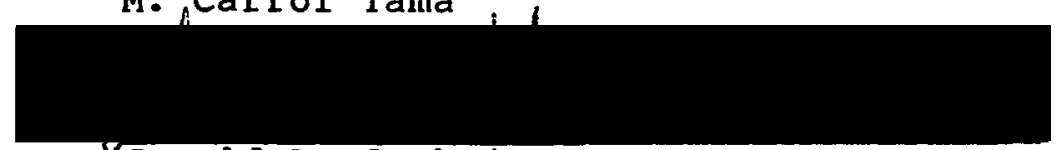

Gerald D. Guthrie
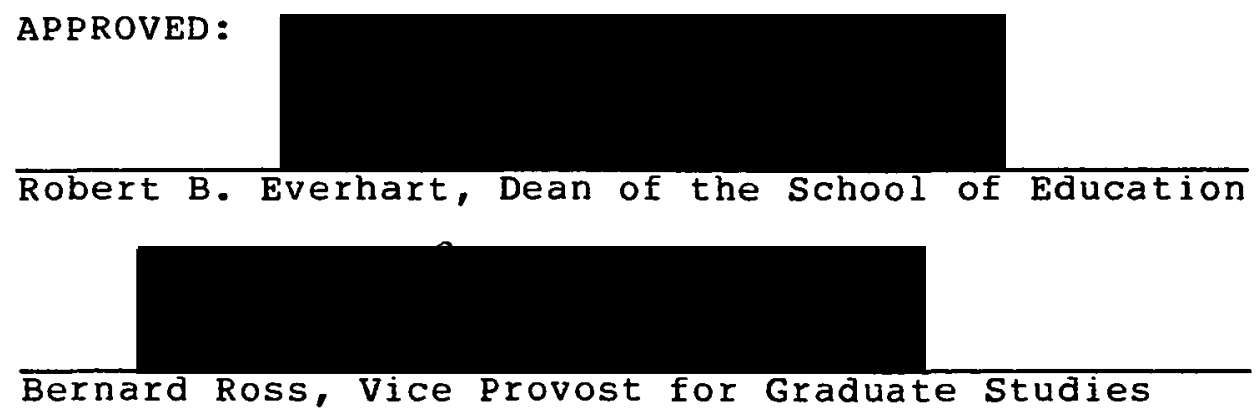
AN ABSTRACT OF THE DISSERTATION OF Christene Kay Jones for the Doctor of Education in Educational Leadership presented May 5, 1989.

Title: Staff Development and the Process of Teacher Change: A Case Study.

APPROVED BY THE MEMBERS OF THE DISSERTATION COMMITTEE:

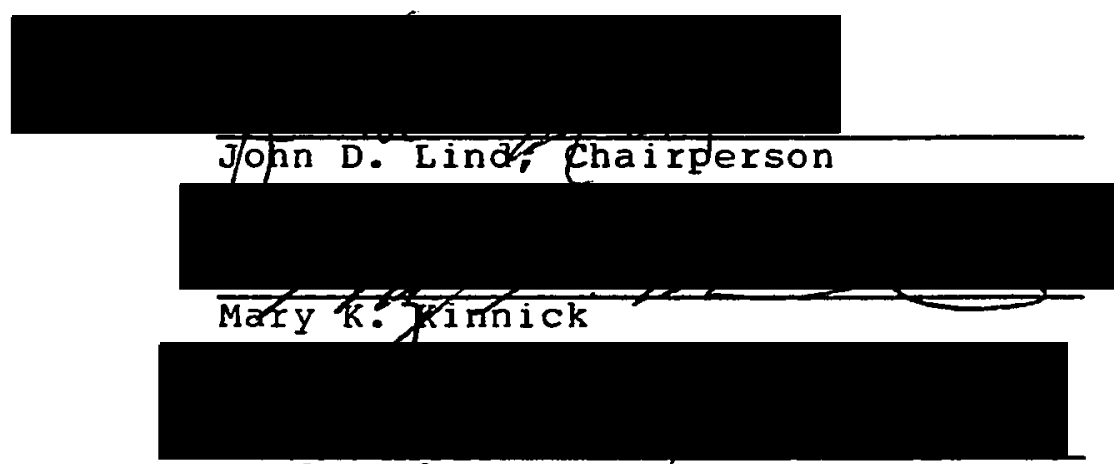

M. Carrol Tama

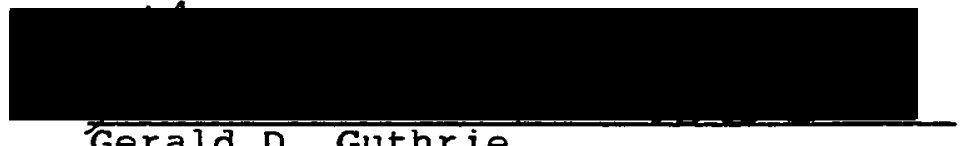

Gerald D. Guthrie

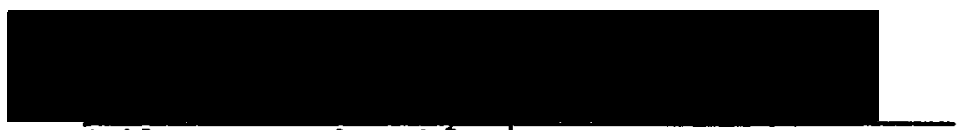

Wilma F. Sheridan

This case study documented a staff development program which was the major component of a public school/university partnership between Portland state University and the Lake Oswego School District, a suburb of Portland, Oregon. A select group of 34 Lake Oswego 
teachers and 4 administrators participated in the Joint Ventures in Instructional Leadership Program which included classes in learning and instructional theory, techniques of peer sharing, instructional strategies and models of teaching, and approaches to the teaching of higher order thinking skills. The program included 7 full days and 4 evenings of instructional training which occurred throughout the 1986-87 school year.

The purpose of the study was to examine the professional growth process of teachers participating in the Joint Ventures Program and determine what effects the program had on instructional decision making and teaching practices. The study provides a full description of the program including: its background; assumptions, goals, and objectives; the selection process and characteristics of teacher participants; the planning process; and the program's content and activities. In addition, the study addresses the following questions:

1. How did teachers perceive their professional growth experience?

2. Did participation in the program bring about any changes in how teachers made instructional decisions?

3. What skills and strategies, acquired through program participation, did teachers use and incorporate into their normal repertoire of teaching practices? 
Participant observation was the primary method of data collection used in this study. Other data collection techniques including interviews, questionnaires, video tapes, and documentation were also employed to provide multiple sources of evidence, thereby increasing construct validity of the study. These observational data were integrated and assembled into a chronological, narrative record of events, resulting in a descriptive account of the staff development process as experienced by Joint Ventures Program participants. The results of this case study indicated that the Joint Ventures Program was effective in promoting desired changes in teachers' approaches to instructional decision making and classroom practices. Several factors were found to influence these changes including a norm of collegiality, School District support, and an ongoing planning process based on participant feedback. The workshop instructor, teacher training activities, and program scheduling also affected the outcomes of the program. Joint Ventures Program participants viewed their overall professional growth experience in a very positive light. 


\section{ACKNOWL EDGMENTS}

I am indebted to a number of individuals who have supported and assisted me in this project.

First, I wish to thank my parents for teaching me the values of perseverance and patience, which were necessary during this project. My family's love, understanding, and encouragement brought special meaning to this endeavor.

My friends and colleagues deserve special recognition for the interest, enthusiasm, and support they offered me during my dissertation process.

I would like to acknowledge the group of participants of the Joint Ventures program for their outstanding efforts to learn and grow as professionals. Grateful appreciation is extended to my fellow leadership team members, Bill Korach and Nancy Nagel, who dedicated themselves to the success of the program.

My doctoral advisory committee was extremely supportive and helpful in providing valuable recommendations for this study. Special thanks go to the chairperson of my committee, Dr. John Lind, whose academic assistance and moral support were a great help to me. 
Finally, I am most appreciative of the efforts of Sister Olivianne Santilli, who provided not only expert typing, but also her prayers, patience, and support. 
TABLE OF CONTENTS

PAGE

ACKNOWL EDGEMENTS • • • • • • • • • • • • • • • i i

LIST OF FIGURES - . . . . . . . . . . . . . . - viii

CHAPTER

I INTRODUCTION . . . . . . . . . . 1

Rationale for the study . . . . 1

Purpose of the Study . . . . . 4

Significance of the Study . . . 5

Methodology . . . . . . . . 6

Definition of Terms ...... 7

Summary . . . . . . . . . 10

I I REVIEW OF THE LITERATURE - - • • • • 11

Introduction . . . . . . . . 11

Definitions and Interpretations . 11

Purpose and Importance - . - . 14

Major Weaknesses of

Inservice Education . . . 16

Elements of Effective

Inservice Education . . . . 23

Goals and Content

The Processes of Inservice Education

Organizational Context

Summary of the Literature Review 


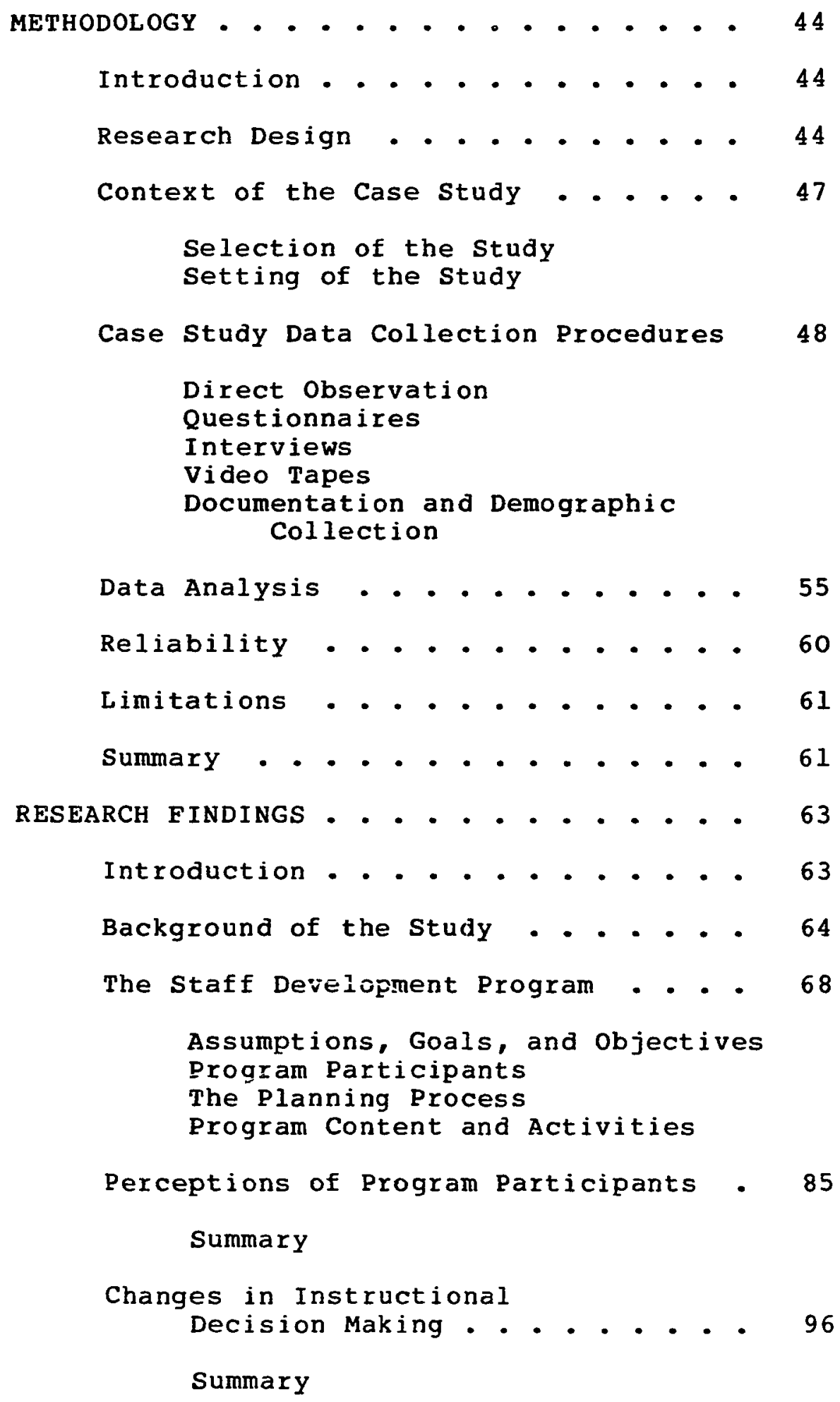


Skills and Strategies Used and Incorporated into Classroom Teaching Practices . . . . . 99

Summary

V DISCUSSION, CONCLUSIONS AND RECOMMENDATIONS . . . . . . . . . . 105

Introduction . . . . . . . . 105

Discussion . . . . . . . . . 105

Recommendations . . . . . . . 113

Suggestions for Future Study . . . . 115

REFERENCES . . . . . . . . . . . . . . 117 APPENDICES
A SCHEDULE OF JOINT VENTURES STAFE DEVELOPMENT SESSIONS • • • . . • • • • 125
B COVER LETTER AND QUESTIONNAIRE • . . . . 127
C JOINT VENTURES PROGRAM PARTICIPANTS . . . 133
D JOINT VENTURES PROGRAM OUTLINE • • • • • . 135
E JOINT VENTURES PROGRAM CONTENT . . • • • . 138 


\section{LIST OF FIGURES}

FIGURE

PAGE

1. Conceptual Framework of the Study . . .

2. Schedule of Staff Development Sessions Spaced over a Period of 30 Weeks from October, 1986 through April, 1987. . . . 
CHAPTER I

\section{INTRODUCT ION}

\section{RATIONALE FOR THE STUDY}

In recent years great strides have been made in identifying schooling practices that are most effective in helping students learn. The classic works of Weber (1971), Brookover (1979), and Edmonds (1979) have brought to light the characteristics of effective schools. Such schools share the following common elements: (1) high staff expectations and morale; (2) clear leadership from the principal; (3) well-defined goals for the school; (4) a considerable degree of control by the staff over instructional and professional development activities; and (5) a positive school climate (Purkey and Smith, 1982). Although much research has been done to determine the common elements of effective schools, little systematic attention has been given to the identification of reliable means by which schools can, in fact, become more effective (Dillon-Peterson, 1981).

In a recent review of research for school improvement, Mackenzie (1983) wrote that "the question of what is important in school effectiveness may now be less significant than the question of what can be changed for 
the least cost and the most results" (p. 14). He concluded that the greatest need at this time are studies that record the process of school improvement in detail. Research that describes the process of educational change will add significantly to our view of how to design effective educational programs.

The professional development of teachers has long been viewed as a necessary condition for school improvement (Rubin, 1978). Joyce (1981) suggested that "substantial, continuous staff development is essential to the improvement of schooling and, equally important, to the development of the capability for the continuous renewal of education" (p. 117). While staff development is increasingly recognized as a critical concern for school districts, there also seems to be a consensus that current practices are generally ineffective. According to Rubin, educators need to develop a clear concept of inservice education that enables them to design and implement more effective staff development programs.

This case study examined a staff development program which was the heart of a public school/university partnership between Portland State University and the Lake Oswego School District, a suburb of Portland, Oregon. A select group of 34 Lake Oswego teachers and 4 administrators participated in the Joint Ventures in Instructional Leadership Staff Development Program which 
included classes in learning and instructional theory, techniques of peer sharing, instructional strategies and models of teaching, and approaches to the teaching of higher order thinking skills. The program included 7 full days and 4 evenings of instructional training which occurred throughout the 1986-87 school year.

This program was selected for investigation because of its unique characteristics. One of its distinguishing features was the sharing of resources between the University and the School District. Another uncommon element of the program was its content which focused on the teaching of thinking. Based on emerging research in that area, the program's approach to instructional improvement was oriented toward intellectual inquiry rather than predetermined solutions or established frameworks for instruction. Finally, a unique group of teachers participated in the program. These veteran teachers, representing all grade levels and curricular areas, were identified as instructional leaders. This unusual combination of elements made this program worthy of investigation as it offered this researcher a rare opportunity to gain insight into the factors influencing the staff development process. 
PURPOSE OF THE STUDY

The purpose of this study was to examine the professional growth process of teachers participating in the Joint Ventures in Instructional Leadership Staff Development Program and determine what effects the program had on instructional decision making and teaching practices. This case study provides a full description of the program including: how the program related to the School/University partnership; assumptions, goals, and objectives; the selection process and characteristics of teacher participants; the planning process; and program content and activities. Within this context the following questions were addressed:

1. How did the teachers perceive their professional growth experience?

2. Did participation in the program bring about any changes in how teachers made instructional decisions?

3. What skilis and strategies, acquired through program participation, did teachers use and incorporate into their normal repertoire of teaching practices? This study describes the process of professional growth within a unique setting. Descriptive data about the context, activities, and perceptions of those involved in the Joint Ventures Program will create a comprehensive, holistic portrayal of the staff development experience. The findings of this research will add to the knowledge 
base used to design more effective staff development programs.

\section{SIGNIFICANCE OE THE STUDY}

Edmonds (1982) suggested that much more is known about the characteristics of school effectiveness than about how they become effective. Since little is known about the process of school improvement, particularly as it relates to the vital element of professional growth of educators, detailed descriptions of the staff development process become important. Wood, Thompson, and Russell

(1981) wrote:

The work ahead of us is to build flowing systems of staff development which help educators enrich their lives and competence, faculties improve their schools, and school systems initiate curricular and organizational changes. Until systems of staff development are pervasive, implementing ad hoc programs will be the norm. (p. 59)

Since staff development will be a priority for the foreseeable future, it is essential that educators gain a fuller understanding of this exceedingly complex process. Knowledge generated by descriptive studies is useful in evaluating existing professional growth programs, as well as aiding in the development of new programs. This study, which employs qualitative research techniques, creates a comprehensive picture of the staff development process as it is experienced by program participants. Although this research is limited to a single case study, it contributes 
uniquely to our knowledge of individual, organizational, social, and political events that influence the outcomes of professional development programs.

\section{METHODOLOGY}

A case study method was deemed the research design most appropriate to the purpose of this study, which was to generate rich, descriptive data about the context, activities, and perceptions of teachers and administrators as they were involved in the staff development process. According to $Y$ in $(1984)$, the case study method is called for whenever an empirical inquiry must examine a contemporary event within its natural context. The research procedures utilized in this study are based on the assumptions that the meaning and process of professional growth is vital in understanding the elements of successful staff development practices, and observation of staff development participants in their real-life context is essential to describing their behavior. Participant observation was the primary method of data collection used in this study. Other data collection techniques, including interviews, questionnaires, video tapes, and documentation, were also employed to provide multiple sources of evidence, thereby increasing construct validity of the study. 
Data analysis included organizing and interpreting collected material. Observational data were assembled into a chronological, narrative record of events. Other data were analyzed and integrated into the record, resulting in a descriptive account of the staff development process as experienced by participants of the Joint Ventures in Instructional Leadership program.

\section{DEFINITION OF TERMS}

ADVANCE ORGANIZERS (Joyce and Weil, 1986) is a teaching model designed to provide learners with a cognitive structure for understanding content presented through lectures and a variety of other media. CONCEPT ATTAINMENT (Joyce and Weil, 1986) is a model of teaching that focuses on having students categorize people, places, or events into classes according to certain cues provided by positive or negative exemplars; the teacher tests the students' attainment of the concepts by providing additional unlabeled data and assists them in recalling and analyzing the thinking strategies they employ .

CONCEPT FORMATION (Joyce and Weil, 1986) is a model of teaching in which the teacher, through eliciting questions, moves the students from concept formation, through interpretation of data gathered, to application of the principles involved. 
CONCEPT MAPPING is a learning activity where students, given content materials, are required to present main ideas within the framework of a graphic organizer, or chart, which shows relevant concepts and their relationships to each other.

COOPERATIVE LEARNING (JOYce and Weil, 1986) is a model of teaching designed to encourage students to define problems, explore various aspects of the problem, collect relevant data, develop hypotheses, and test them. The teacher organizes and facilitates this small group process.

DIRECT INSTRUCTION (JoYce and Weil, 1986) is a model of teaching where material is presented to students in units ranging from the simple to the complex. Students work progressively through the units and are tested at the end of each to determine their mastery of the material. EXPRESSIVE LEARNING is a process involving purposeful remembering and skillful performance by the learner. The teacher requires students to define, organize, pattern, synthesize, and restructure information.

INQUIRY TRAINING (Joyce and Weil, 1986) is a teaching model designed to engage students in the process of causal reasoning and become more skilled in asking questions, forming concepts and hypotheses, and testing them. 
INSERVICE EDUCATION, PROFESSIONAL DEVELOPMENT, and STAFF DEVELOPMENT are terms used interchangeably in this dissertation to describe any planned process designed to provide teachers and school administrators with continued learning opportunities and experiences aimed at the improvement of the quality of instruction (Harris, 1980). INSTRUCTIONAL LEADER is a term used in this dissertation to describe any teacher with proven expertise in teaching who has demonstrated the ability to lead and influence other teachers.

METACOGNITION refers to a cognitive process whereby students develop a consciousness of their own thinking patterns.

\section{NORMAL REPERTOIRE OF TEACHING PRACTICES refers to}

the teacher's internalized store of instructional strategies which are used in their ongoing, regular teaching activities.

PEER SHARING is the reciprocal process of collegial sharing and exploration of instructional alternatives based on nonevaluative observations of classroom teaching. The purpose of this activity is to establish a common basis for discussing instructional issues, broaden the range of instructional methods and strategies, promote transfer of newly learned skills into classroom instruction, and foster self-analysis and growth based on observation and feedback. 
PROBLEM SOLVING refers to a learning activity whereby students define or describe a problem, determine the desired outcome, select possible solutions, test trial solutions, evaluate the outcome, and revise these steps where necessary.

SYNECTICS (Joyce and Weil, 1986) is a teaching model which stimulates creative thinking; the teacher elicits metaphoric comparisons from students in an effort to prod their imaginations to transform commonplace and familiar things into new structures and images.

\section{SUMMARY}

This case study examines the process of staff development as it relates to school improvement. It contributes significantly to our knowledge about the subtle interplay among various factors involved in the professional growth process. The study provides descriptive data that will enrich the current 1 iterature on inservice education and add to the knowledge base used to design more effective professional development programs for teachers. 
CHAPTER II

REVIEW OF THE LITERATURE

\section{INTRODUCTION}

This chapter reviews the current literature relevant to inservice teacher education. As an overview, this chapter presents varying definitions and interpretations of inservice education and discusses its purposes and importance. Major weaknesses found in inservice education are also addressed. Finally, this chapter reviews elements common to effective inservice education programs.

\section{DEFINITIONS AND INTERPRETATIONS}

A range of perceptions about the nature of inservice teacher education is reflected in the variety of definitions and interpretations of inservice found in the literature. Fenstermacher and Berliner (1983) defined inservice education as "the provision of activities designed to advance the knowledge, skills, and understandings of teachers in ways that lead to changes in their thinking and classroom behavior" (p. 4). Edelfelt (1975) defined inservice as "any professional development activity that a teacher undertakes singly or with other teachers after receiving her or his initial 
teaching certificate and after beginning professional practice" (p. 5). He went on to say that inservice education should be reconceptualized within the context of teachers' changing roles, and that a collaborative effort among teachers, school administrators, colleges and universities, and state departments of education is essential to the reconceptualization process.

The need for collaboration in inservice education is expressed by other writers as well. Joyce, Hersh, and Mckibbin (1983) suggested that inservice for teachers is best determined and delivered through an open collaborative effort among public representatives, college and university faculty, school administrations, and teacher organizations at all levels of decision making. Similarly, walter (1984) recommended a close working relationship between school systems and universities. He argued that cooperative inservice programs are desirable because of teachers' need to be kept abreast of new knowledge generated by the university.

Advocacy of more school-focused forms of inservice is not uncommon. According to Howey (1981), inservice activities mist be focused on the specific needs and interests of teachers in their work environment as well as on school-wide interests and concerns. He suggested that program improvement is best achieved when professional development is conceptualized in a framework which 
emphasizes the interaction of social/organizational

variables with personal/psychological variables.

Hite (1977) argued that the definition of inservice depends on who defines it, and that there may be no specific guidelines for inservice education that are appropriate to every situation. He wrote:

Unlike the preparation of beginning teachers, inservice has no tradition of what constitutes a basic program. Different perceptions imply different sets of values--what ought to be the way to undertake professional development. Because values do not lend themselves to technical criticism, each different definition may be legitimate for its supporters. The way inservice is perceived seems to determine the activities and content of programs. Thus, there are very different perceptions of inservice education which lead to equally different programs of operation. (p. 2)

While the term inservice education has traditionally been employed to refer specifically to teachers' professional growth activities, other closely related terms in common usage are professional development. continuing education, on-job training, and professional growth. Staff development, a term which is widely employed in other professions, has also come increasingly to be used interchangeably with inservice education (Harris, 1980).

Although specific definitions, contexts, and formats of inservice education vary, most inservice programs share a common purpose: to bring about change (Guskey, 1985). The primary task of inservice is to provide educators with 
continuous learning opportunities and experiences that will foster personal and professional growth, resulting in better learning for students and a growth-oriented ecology in all schools (Dillon-Peterson, 1981).

\section{PURPOSE AND IMPORTANCE}

In recent years advances in research on effective schools and the variables that contribute to instructional effectiveness have spurred a nationwide interest in the quality of inservice education (Harris, 1980). This emphasis, which developed in the 1970s, indicates increased awareness of the important role that inservice teacher education plays in the process of educational change. Educators generally agree that the three major outcomes of effective inservice programs are changes in (1) teachers' beliefs and attitudes, (2) teachers' classroom practices, and (3) students' learning outcomes (Fullan, 1982; Griffin, 1983; Guskey, 1985). Significant improvement of educational programs cannot be accomplished without a major systematic attempt to bring about these changes through inservice education (Griffin, 1982;

Guskey, 1985). As Harris (1980) put it, inservice education is ". . the most important developmental task to which the schools and colleges of the nation must attend in the 1980s" (p. 15). 
Among those most interested in the quality of inservice education are teachers. Rubin, citing Harris (1980), stated that "teachers, as a whole, are remarkably open to new methodology--even hungry for it" (p.37). The series of studies into the process of change at the school level carried out by the Rand Corporation revealed that teachers are motivated to participate in professional growth activities primarily because they believe such activities will help them to increase their instructional effectiveness (Berman and McLaughlin, 1978). Inservice activities axe generally seen by teachers as the most viable means of expanding their knowledge and skills, contributing to their personal and professional growth, and improving their effectiveness with students (Fullan, 1982).

In response to public appeals and legal mandates for accountability in the schools, states and school systems are turning in increasing numbers to inservice education as a means of school improvement (Toch, 1982). In recent years all states have ceased granting lifetime teaching certificates and are now requiring teachers to develop and improve their professional skills through various types of inservice activities. In addition, state and federal funds have stimulated inservice developments such as Teacher Corps, teacher centers, and regional education service centers (Hite, 1977). 
The burgeoning national interest in the quality of inservice education has been stimulated by a number of trends in our society. Declining school enrollments and budget cuts have resulted in low teacher turnover. Toch (1982) noted that teacher supply-and-demand projections indicate that most of today's teachers will still be on the job ten years from now. Consequently, inservice education will play an important role in keeping a mature teaching force abreast of advances in instructional techniques and new technology.

Inservice education has also been used as a means to facilitate and communicate a curriculum that reflects rapidly changing social conditions (Dillon-Peterson, 1981). Curricular content, such as moral education, drug education, sex education, multicultural education, and death education, implies new roles for teachers. Because these topics are dealt with superficially at the preservice level, it is through inservice education that these issues must be addressed in order for teachers to remain current in their profession (Willie and Howey, 19801

MAJOR WEAKNESSES OF INSERVICE EDUCATION

While there is strong evidence of a growing need for the ongoing professional development of teachers, it is also apparent that inservice efforts have had many 
failings. Wood and Thompson (1980) are among the critics of inservice education who described current practices as a waste of time and money. They argued that most inservice efforts consist of fragmented workshops and courses that are ineffective and irrelevant to teachers' needs due to the fact that they focus on information dissemination rather than stressing practical classroom application of the information. Rubin (1978) suggested that traditional teacher inservice programs are inadequate, suffering from "a lack of energy, precision, direction and imagination" (p. 4). Howey and Vaughan

(1983) described current inservice education as

$$
\begin{aligned}
& \text { of resources) enterprise that is fragmented, not } \\
& \text { frequently engaged in on a continuing basis by } \\
& \text { practitioners, not regarded very highly as it is } \\
& \text { practiced, and rarely assessed in terms of teacher } \\
& \text { behavior and student learning outcomes. (p. 97) }
\end{aligned}
$$

Other reports by Dillon-Peterson (1981), Howey and Joyce (1978), Lawrence, Baker, Hansen, and Elzie (1974), Petracek (1986), and Van Cleaf and Reinhartz (1984) have also found teacher inservice education to be a system with many problems.

Inservice education programs are most often designed to foster the professional development of classroom teachers; however, teachers often are not consulted during the planning stages nor are they encouraged to participate in the implementation of inservice activities. Consequently, teachers' needs frequently go unaddressed, 
and their sense of ownership in the inservice program is considerably reduced (Locke, 1985). The lack of teacher control and responsibility for inservice activities results in charges that inservice programs are irrelevant to teachers' needs (Houston, 1980; Petracek, 1986; Toch, 1982) .

A Tennessee study involving 646 teacher respondents sampled from all 13 school districts in the state was undertaken to determine attitudes of teachers toward current inservice practices as well as some general beliefs about inservice education (Brimm and Tollette, 1974). Eighty-nine percent of the respondents agreed that teachers should have some freedom in the selection of inservice activities, and 96 percent felt that inservice programs should reflect different interests. In addition, 93 percent believed teachers should be involved in the planning of inservice activities, 86 percent felt that released time should be provided, and 90 percent thought that emphasis should be placed on performance objectives. However, in responding to items about current realities of inservice, 73 percent of the teachers reported that inservice activities were not relevant, 63 percent did not like to attend, 44 percent felt that inservices were not well-planned, and 31 percent believed that inservice activities were essentially worthless. They further 
complained that inservice programs lacked specificity of objectives and provided inadequate follow-up.

One of the more comprehensive reviews of research on inservice education done by Lawrence and his colleagues (1974) identified many problems with teacher inservice. Among these was a lack of adequate planning. In fact, less than one fifth of the 97 studies reviewed concerned any kind of comprehensive inservice planning or general school program development. In addition, only slightly more than one fifth of the programs involved teachers in the selection of goals and activities of inservice programs. Teacher-initiated and teacher-directed training activities were found to be seldom used in inservice education programs; however, this approach to the delivery of inservice programs was associated with successful accomplishment of goals.

- Lawrence and his team (1974) also reported that most inservices were conducted as workshops in the school setting. However, the majority of school-based programs were conducted by university faculty and were focused on increasing teachers' knowledge base rather than directed toward the improvement of classroom teaching practices. In addition, only a few of the programs included training in the use of observation techniques, which were found to have a positive impact on teachers' ability to analyze and 
make desired changes in their teaching behavior. Lawrence

and others (1974) concluded:

The message in the findings seems clear: the inservice programs that have the best chance of being effective are those that involve teachers in planning and managing their own professional development activities pursuing personal and collective objectives, sharing, applying new learnings and receiving feedback. (p. 17)

In an extensive review of research on inservice practices and curricular change conducted by fullan and Pomfret (1977), problems similar to those found in the Lawrence et al. (1974) study were observed. One of the many problems identified in their study was the lack of long-range planning for the implementation of curricular changes. The research suggested that:

Implementation requires organizational changes in role and role relationships. The role occupants are required to alter their usual ways of thinking about themselves and one another and their characteristic ways of behaving towards one another within the organization. (p. 337)

These changes require multiyear planning and practice to be successfully accomplished.

Another problem identified by Fullan and Pomfret (1977) was that of inadequate assessment for curricular implementation. They observed that the effects of inservice on teacher performance or student achievement are rarely, if ever, reliably measured. Self-reporting measures commonly used, such as surveys, questionnaires, 
and focused interviews usually reflected teacher attitudes rather than actual implementation practices.

Fullan (1982) stated, "Nothing has promised so much and has been so frustratingly wasteful as the thousands of workshops and conferences which led to no significant change in practice when teachers returned to their classrooms" (p. 263). In a review of inservice education, he summarized the reasons for failure in seven points:

1. One-shot workshops are widespread but are ineffective.

2. Topics are frequently selected by people other than those for whom the in-service is intended.

3. Follow-up support for ideas and practices introduced in in-service programs occurs in only a very small minority of cases.

4. Follow-up evaluation occurs infrequently.

5. In-service programs rarely address the individual's needs and concerns.

6. The majority of programs involve teachers from many different schools and/or school districts, but there is no recognition of the differential impact of positive and negative factors within the systems to which they must return.

7. There is a profound lack of any conceptual basis in the planning and implementing of in-service programs that would ensure effectiveness. (p. 263)

Fullan (1982) also suggested that approaches to inservice education have been based on weak conceptions of how learning occurs. 
Studies, unfortunately, point to the conclusion that the majority of inservice education experiences fail to meet the needs of teachers, especially those needs connected with new programs (Fullan, 1982). Teachers often do not develop the expected skills, or, where skills are developed, transfer into practice is often short-lived (Fullan; Crandall and Loucks, 1982). These shortcomings are due to many reasons, including content and delivery that is fragmented, narrow in focus, and not based on assessed needs of teachers. Inservice activities found to be generally ineffective are those that lack specificity of objectives, are focused on expanding teachers' knowledge base rather than improvement of classroom teaching practices, and are not included in a district's priority goals. Weaknesses in the processes of inservice include practices such as one-shot workshops, failure to include teachers in the planning and implementation of activities, and a lack of adequate program assessment, particularly in terms of teacher behaviors and student outcomes. The most outstanding weakness, according to Fullan, is a lack of follow-up support for the application of ideas. He stated, "The absence of follow-up after workshops is without doubt the greatest single problem in contemporary professional development" (p. 287). 
ELEMENTS OF EFFECTIVE INSERVICE EDUCATION

Comprehensive reviews of the literature show that inservice education is a complex system consisting of several dimensions that can influence the outcomes of inservice programs (Gall, Haisley, Baker, and Perez, 1982; Gall and Renchler, 1985; Lawrence and Harrison, 1980; Joyce, Howey, and Yarger, 1976; Goodlad, 1975; and Lawrence et al., 1974). The study by Gall and his colleagues identified a set of 27 dimensions that characterize effective inservice programs, while Lawrence and Harrison's synthesis resulted in the suggestion of 12 important elements of inservice education. Sparks (1983) succinctly grouped elements of effective inservice into three categories including goals and content, inservice processes, and the organizational context of inservice education. The intention of this review is to utilize these three broad categories as a framework for the discussion of effective inservice practices.

Goals and Content

Lawrence and Harrison's (1980) meta-analysis of the inservice literature found that inservice programs in which teachers chose goals and activities for themselves were more effective than preplanned programs. Lawrence and Harrison suggested that teachers ought to be involved in the planning of inservice activities to help insure 
that goals and content are relevant to their needs. Holly (1982) interviewed $100 \mathrm{~K}-12$ teachers and found that, "The single most important factor determining the value teachers placed on an inservice education activity was its personal relevance" (p. 418). Locke (1985) suggested that inservice programs shaped by the needs of teachers produce a more positive attitude toward inservice which, in turn, leads more readily to the development of greater teacher effectiveness. He concluded that, "participation in determining the content and nature of inservice programs is essential in the creation of a program that will lead to the acceptance and implementation of teaching strategies that will improve education" (p. 7).

Adult learning theory has been linked with the inservice education of teachers and appears to offer support for the above findings. Knox (1977) suggested that it is important to establish a learning climate that encourages and allows adult learners to consider their own expectations as well as select learning objectives which are attractive and realistic. He wrote, "The adult's motivation and cooperation in the learning activity is more likely when the tasks are meaningful and of interest to the learner. Active interest and participation are more likely when the learner helps identify objectives, selects learning tasks, and understands procedures" (p. 411$)$ 
Research on teacher preferences and values suggests that inservice topics relating to the affective growth of students is a high priority for teachers. A study conducted by Prawat and Anderson (1981) found that elementary teachers consider their primary task to be addressing students' affective needs. Similarly, Harootunian and Yarger (1981) found that the majority of teachers felt that involving their students affectively in instruction was a priority. Another study conducted by Schurr and his colleagues (1980) revealed that inservice topics concerning the improvement of student motivation and attitudes were preferred by teachers. Lortie's (1975) work in the area of teacher motivation also appears to support the notion that, given the choice, teachers would opt for inservice topics that have a direct bearing upon their interaction and relationship with students. The research on curriculum implementation indicates that the explicitness and complexity of a curriculum or inservice content has an effect on its implementation (Fullan and Pomfret, 1977). Casper and Roecks (1982) noted that the more defined and more specifically detailed the innovation, the greater the likelihood of successful implementation. Hall and Loucks (1980) stated, "Research and experience have shown that unclear expectations are one way to guarantee nonimplementation. Teachers appreciate clear objectives--they need to know what they 
are expected to do and how their roles are to change" (p. 16). Hall and Loucks further discussed how the complexity of the innovation affects the likelihood of change. They wrote that, "When the innovation is complex, - - major components should be phased in one or a few at a time" (p. 18). Complex teacher objectives require a substantial period of time to be successfully accompli shed.

Summary of Findings. The literature suggests that inservice education is most effective when teachers are involved in the planning process. Inservice activities ought to have goals and content that are explicit, operationable, and relevant to the needs of teachers, particularly those needs relating to the day-to-day interactions and relationships with students. Additionally, the complexity of teacher objectives and inservice content should be considered in determining the length of time needed to accomplish inservice goals.

The Processes of Inservice Education

Scheduling. Research on instructional improvement indicates that traditional inservice programs consisting of "single-shot" workshops are relatively ineffective (Lawrence et al., 1974). Educators are increasingly advocating that a long-term perspective is required for successful implementation of inservice goals (Fullan and Pomfret, 1977). Loucks and Pratt (1979) suggested that a 
substantial time frame is needed for effective implementation: "Research indicates that three to five years are necessary to implement an innovation that is significantly different from current practice" (p. 213). One reason for spacing inservice activities over time is the concept of "mutual adaptation" introduced by Berman and McLaughlin (1976). They found that desired changes in teaching behaviors were more likely to occur if teachers were given a period of time to adapt, modify, and integrate new techniques into classroom practice. The Concerns-Based Adoption Model (CBAM) (Hall, Wallace, and Dossett, 1973) provides another rationale for the effectiveness of long-term change efforts. CBAM is based on the premise that change is a developmental process rather than an event. Individual differences and concerns at various stages in the change process must be the focus for the design and delivery of inservice activities. From a concerns-based perspective, an effective inservice program would be a continuing process that adapts to teachers' changing needs. This notion is consistent with Knowles' (1978) research into adult learning. He wrote, "Individual differences among people increase with age; therefore, adult education must make optimal provision for differences in style, time, place, and pace of learning" (p. 31). 
According to Sparks (1983) content of inservice programs should be given in small "chunks" spaced over time. She reported that a series of four to six threehour workshops spaced one to two weeks apart appeared to be an effective inservice schedule. This time frame provides the opportunity for ongoing discussion of problems and concerns related to implementation as well as allows for the gradual change inherent in the concernsbased approach and in the notion of mutual adaptation (sparks) .

Training Activities. The review of teacher training research by Joyce and Showers (1980) is central to the search for attributes of effective inservice programs. In their study, which addressed the issue of transfer of skills into classroom practice, Joyce and Showers distinguished between two purposes of inservice training: "horizontal" transfer (the fine tuning of existing skills) and "vertical" transfer (the incorporation of new learning into a repertoire of teaching strategies). They argued that transfer which involves the refinement of existing skills is generally easier to achieve. "Vertical" transfer is a more complex process as it involves the mastery of new content and/or strategies and requires teachers to think differently and organize instruction in new ways. 
Joyce and Showers (1980) also distinguished between four levels of impact of training and five components of training. This enabled them to determine, within the body of research on training, the extent to which each kind of training component contributed to each level of impact. The four levels of impact include: awareness; the acquisition of concepts and organized knowledge; the learning of theory and skills; and, finally, their application to instructional problem solving. Joyce and Showers reported that impact on student learning results only when the fourth level of impact is reached. Their five components of training include:

1. Presentation of theory or description of skill or strategy.

2. Modeling or demonstration of techniques or models of teaching.

3. Frequent and varied practice in simulated and classroom settings.

4. Structured and open-ended feedback to provide information about performance.

5. Coaching for application (a form of follow-up support or technical assistance).

Joyce and Showers summarized their findings as

follows:

For maximum effectiveness of most in-service activities, it appears wisest to include several and perhaps all of the training components we have Iisted... Where the 
fine tuning of style is the focus, modelling, practice under simulated conditions, and practice in the classroom, combined with feedback, will probably result in considerable changes. Where the mastery of a new approach is the desired outcome, presentations and discussions of theory and coaching to application are probably necessary as well. If the theory of a new approach is well presented, the approach is demonstrated, practice is provided under simulated conditions with careful and consistent feedback, and that practice is followed by application in the classroom with coaching and further feedback, it is likely that the vast majority of teachers will be able to expand their repertoire to the point where they can utilize a wide variety of approaches to teaching and curriculum.

If any of these components are left out, the impact of training will be weakened in the sense that fewer numbers of people will progress to the transfer level (which is the only level that has significant meaning for school improvement). The most effective training activities, then, will be those that combine theory, modelling, practice, feedback and coaching to application. The knowledge base seems firm enough that we can predict that if those components are in fact combined in in-service programs, we can expect the outcomes to be considerable at all levels. (p. 384-385)

The meta-analysis conducted by Lawrence and Harrison (1980), although not categorized in a framework, resulted in conclusions similar to those of Joyce and Showers. Lawrence and Harrison found that inservice programs which are most effective are those that:

1. Do not rely on lectures as the primary mode of delivery.

2. Use various program patterns emphasizing teacher responsibility, such as self-instruction, peer study groups, college courses, and one-on-one consultation. 
3. Involve participants both in receiving new ideas and in putting them into practice, rather than in receptive roles to the exclusion of active roles, or vice versa.

4. Include elements which could be tried out in classrooms or in simulations, in order that a novice may receive immediate feedback from a skilled person.

5. Include demonstrations of exemplary practices and provide participants with opportunities to learn skills by observing others.

In addition to the above findings, Lawrence and Harrison (1980) reported that inservice programs tended to be more successful if conducted at the school site. This generalization, however, applied only to inservice programs that emphasized affective change or skill acquisition as the training objective.

Other inservice and school improvement and change literature appears to offer a number of similarly supportive findings for those teacher training practices identified by Joyce and Showers (1980, 1982) and Lawrence and Harrison (1980). The Rand studies of Berman and McLaughlin (1976) found effective inservice activities to include: experiential "teacher specific" training; onsite assistance; peer observation; participative governance; local materials development; and "mutual adaptation" (a process whereby teachers adapt and modify 
new practices to fit their unique situation). The curriculum implementation review by Fullan and Pomfret (1977) found that "intensive" inservice training activities which provided demonstrations, modeling, and feedback mechanisms are necessary to bring about successful change in teacher behaviors. Stallings, Needels, and Stayrook (1978) have also illustrated how an intensive inservice training model including diagnosis of instruction and recommendations for behavior changes, on-site assistance, observation, and feedback has been successful in producing improvements in teacher behavior. The adult development and learning literature lends additional support for the previously discussed reviews of teacher training and school change literature. Bents and Howey (1981) and knox (1987) have recently reviewed a number of "stage" theorists such as Piaget, Kohlberg, Hunt, Sprinthall, and Loevinger, and several "age" theorists such as Havighurst, Houle, Knowles, Gould, and Sheehy. Some of the recommendations which arose from these reviews were that adult learners, such as inservice teachers, require: a variety of learning experiences; frequent, detailed, and supportive feedback; a model that serves as a reference point of desired performance against which to assess progress; time for reflection, discussion, and practice to enable the 
integration of new ideas with role behaviors; and immediately useful content.

Inservice Instructors. Characteristics of inservice program instructors have a significant impact on what participants learn and put into practice (Jones and Steinbrink, 1986; Rappa, 1983). The most successful workshop instructors are those who can communicate effectively with adults. Presenters should be well acquainted with principles of adult learning and development, taking into account individual differences among learners. The instructor also should be aware of teachers' needs and motivations (Knox, 1987). The more information instructors have about participants, "the better they can appeal to the participants' diverse learning needs" (Vacca, 1983, p. 52).

Instructors may be university faculty, teachers, administrators, or other school-related personnel. However, it appears that the most effective inservice instructors are professional colleagues or university personnel who are or have been teachers themselves. Fenstermacher and Berliner (1983) suggest that there is a higher probability of success if the instructors themselves have been "front line troops" because they can more readily identify with the "real world" of classroom teaching. An inservice instructor must be a "good teacher with good interpersonal skills, recognized expertise, and 
the ability to build on the participants' knowledge and experience" (Dillon, 1978, p. 11). Another desirable characteristic of inservice instructors is that of being able to model and demonstrate the teaching behaviors and skills that teachers are expected to apply to their own work settings (Joyce and Showers, 1981; Little, 1981). Joyce and Showers stress the importance of modeling desired teacher behaviors and argue that little change is likely to occur without clear demonstrations of recommended practices.

\section{Summary of Findings. Research offers strong}

support for the notion that an extensive training and implementation program is necessary to affect significant change in teaching practices. It can be concluded that effective inservice activities are diverse in nature, and that theory, modeling, practice, feedback, and follow-up support are important training components. Inservice programs are likely to be successful to the degree that instructors are good communicators, are or have been teachers themselves, and are able to model the skills they are teaching others. The design and delivery of inservice activities should be based on individual differences such as preferred learning modes, learning pace, experience, and background, as well as adapted to teachers' changing needs and concerns. Also, inservice activities are most effective when spaced over time to allow teachers the 
opportunity to reflect upon and gradually integrate new skills into classroom practice.

\section{Organizational Context}

Inservice education is fundamentally a process designed to foster personal and professional growth of individual teachers. Since teachers are members of school organizations, it is likely that the characteristics of these organizations will influence the processes and outcomes of inservice education programs (Gall et al.. 1982; Gall and Renchler, 1985). The importance of the organizational context of staff development efforts was highlighted in the Rand study of educational innovations. McLaughlin and Marsh (1978) summarized the study's implications for teacher inservice as follows:

In summary the Rand study suggests that effective staff development activities should incorporate five general assumptions about professional learning:

- Teachers possess important clinical expertise. - Professional learning is an adaptive and heuristic process.

- Professional learning is a long-term, non-linear process.

- Professional learning must be tied to school-site program-building efforts.

- Professional learning is critically influenced by organizational factors in the school site and in the district.

These assumptions support a view of staff development emphasizing learning for professionals 
as part of program building in an organizational context. (p. 90-91)

The following discussion addresses three organizational factors that are likely to influence the effectiveness of professional growth programs including forms and formats of inservice, peer support, and administrative support. Forms and Formats of Inservice. Inservice education emphasizes school improvement through professional development in a variety of forms and formats. Joyce and his colleagues (1976) suggested that the context of inservice education has five general modes, which can be briefly described as follows:

1. Job-embedded. This mode involves on-the-job activities such as school committee work and team teaching .

2. Job-related. This mode includes activities such as district workshops that are held outside of regular school hours.

3. Credential-oriented. This mode is used mainly by those seeking advanced certificates or degrees.

4. Professional organization-related. This mode includes workshops sponsored by professional organizations to help their members remain current in the relevant field of study.

5. Self-directed. This mode includes selfinitiated activities that maintain or improve professional skills. 
Gall and others (1982) suggested that these modes represent different purposes for inservice education. They distinguished four such purposes:

1. Inservice for personal professional development, which corresponds to the self-directed mode and perhaps the professional organization mode.

2. Inservice for credentialling, which corresponds to the credential-oriented mode.

3. Inservice for the purpose of being inducted into the profession . . . first year teachers need a special form of inservice education (called "induction") to help them adjust to full-time teaching and to learn skills not covered in preservice education.

4. Inservice for school improvement, which typically would be done in the job-embedded and job-related modes. (p. 21)

Gall and his team (1982) related the first three purposes to the development of the individual teacher. Inservice for school improvement, however, gives priority to the school organization. Gall and his colleagues maintained that, "Teachers' personal needs may be taken into account, but teachers' roles as members of the school organization are critical to this form of inservice education" (p. 2l).

The notion of school-focused inservice is advocated by many writers. According to Howey (1981), inservice programs should focus upon interests and concerns that are "cross-cutting" in nature, having school-wide as well as individual implications. McLaughlin and Marsh (1978) concluded that staff development programs are more 
effective when activities are closely related to teachers' day-to-day needs and consideration is given to the total school as an organization. Lawrence and Harrison (1980) similarly asserted that the most successful inservice programs are those that are collectively designed by a school faculty to meet general faculty development rather than individual teacher goals. This research suggests that inservice should focus on the school as the primary unit of change, not the district or the individual (Goodlad, 1975).

Peer Support. Research indicates that teachers have a strong preference for inservice programs which provide a framework for close collegial support. Holly (1982) found that most teachers preferred inservice activities that allowed them to share ideas with other teachers: "Teachers described their colleagues as valuable sources of practical ideas and information, helpful advisors on professional problems, the most useful evaluators of teaching skills, and understanding allies." (p. 418) Sparks (1983) observed that teachers appreciated the "personal nature" of inservice workshops that included small group discussion activities. She reported that when teachers were given the opportunity to discuss their problems, successes, and concerns, they felt less isolated and more confident about their ability to make instructional changes. Small groups or "learning teams" 
provide a setting for teachers to share insights, solve problems, and help each other learn (Wood et al., 1981). Peer observation appears to be another means of fostering collegial support. According to Sparks (1983), the peer observation process not only provides teachers with feedback, but stimulates analysis and discussion of the effects of instruction on students. Sparks suggested that peer observation may help break down the "psychological walls" between classrooms, thus reducing the isolation of classroom teaching. She went on to say that peer observation activities should be kept voluntary and completely separate from evaluation to ensure an atmosphere of trust and collaboration.

Coaching is still another staff development activity that provides support and encouragement for teachers as they attempt to use new skills in the classroom. Joyce and Showers (1982) suggested that coaches may be peers, supervisors, principals, college instructors, or others, who are competent themselves in the use of the target skill or strategy. According to Joyce and Showers, coaching includes the giving of technical feedback, the analysis of application, and the provision of companionship. The coaching relationship offers an opportunity for mutual reflection, the checking of perceptions, and the sharing of successes and frustrations (Showers, 1985). 
The adult learning literature gives credence to the notion that effective inservice programs are those which provide a framework for close collegial support. Knox (1987) suggested that effective interpersonal settings for adult learners are both supportive and challenging. A physical and interpersonal learning environment in which adults feel psychologically safe and welcome helps to reduce apprehension brought about by new challenges. Adult learners are more likely to take an active role in learning and problem solving in a setting that is supportive and nonthreatening.

\section{Administrative Support. Administrative support} appears to be a major factor affecting success of teacher inservice programs. The Rand researchers (Berman and Mclaughlin, 1978) found that principals are key people in school improvement and change. They concluded that the more effective principals were likely to be committed to the implementation of inservice goals. Effective principals participated in workshops and assisted teachers in the implementation of newly learned skills and strategies. Leithwood and Montgomery (1982), in a review of the role of the principal in school improvement, similarly concluded that principal participation in all or at least the early sessions of an inservice program increased the likelihood of desired teacher change. 
Loucks and Pratt (1979) found from their research that,". - what the principal does is critical to the success of an implementation effort" (p. 215). Similarly, the role of the principal as an "instructional leader" in bringing about improvements in teaching was emphasized by Lieberman and Miller (1981). Teachers are most likely to improve in schools where the principal is supportive and clearly communicates expectations (Manasse, 1985).

Summary of Findings. The research evidence suggests that the organizational context or environment of staff development efforts significantly influences the outcomes of inservice education. Inservice programs which are focused on school improvement and promote close, personal, and cooperative working relationships among educators are most likely to be successful. In addition, research data reveal that in those schools where implementation of new programs is most successful, principals take an active role in inservice activities and provide teachers with the follow-up support so necessary for the effective transfer of newly learned skills into the classroom setting.

\section{SUMMARY OF THE LITERATURE REVIEW}

Inservice teacher education has long been viewed as a necessary condition for school improvement and will most likely continue to play an important role in the process of educational change. Inservice programs are generally 
aimed at instructional improvement. Educators generally agree that effective inservice programs are those that produce desired changes in teachers' thinking and classroom behavior resulting in increased student learning.

Traditional inservice practices have been widely criticized in that they produce no significant change in teacher behaviors. These practices include one-shot workshops conducted in lecture format with little or no follow-up support for the application of ideas. Inservice topics are often selected by people other than those for whom the inservice is intended and rarely address teachers' individual needs and concerns. Furthermore, most inservice programs lack any conceptual basis in the planning and implementation of professional growth activities that would ensure effectiveness.

In-depth, long-term inservice programs which involve participants in extended periods of training are relatively few, although research shows that substantial periods of time are needed to affect successful change in teaching practices. Successful inservice programs are based on teachers' changing needs and concerns and offer a diversity of learning activities. Important teacher training practices include presentation of theory, modeling, practice, feedback, and follow-up support. Inservice for school improvement that provides a framework 
for close collegial support and involves the active participation of the school principal is most effective in producing lasting changes in teacher behavior.

Although the literature identifies many factors which contribute to the effectiveness of staff development programs, there exists a paucity of information about how these factors apply to particular contexts. Relatively few studies have actually examined the evolution of professional growth. This case study provides an indepth, comprehensive description of the staff development experience as it occurs in its natural setting, increasing our understanding of the nature of the professional growth process. 
CHAPTER III

METHODOLOGY

INTRODUCTION

This chapter presents the research design utilized in the study and includes the purpose and rationale for selecting this research methodology. Included in the discussion is a description of the study's setting as well as an overview of how the study was selected. This chapter further describes each data collection strategy and the subjects specific to each procedure. An account of data analysis techniques is also given. Finally, a dicussion of reliability, limitations, and a chapter summary is provided.

\section{RESEARCH DESIGN}

Schatzman and Strauss (1970) reported that "a method of inquiry is adequate when its operations are logically consistent with the questions being asked and when it adapts to the special characteristics of the thing or event being examined" (p. 7). According to Blumer (1966), the appropriate method for studying an interactive social situation is "to approach the study of group activity 
through the eyes and experience of people who have developed the activity" (p. 689).

The purpose of this study was to produce descriptive data about the context, activities, and perceptions of a selected group of teachers and administrators participating in a staff development program. A qualitative case study method was chosen as the research design most appropriate to the focus of this examination. Yin (1984) asserted that the need to use case studies arises whenever an empirical inquiry must examine a contemporary phenomenon within its real-life context, especially when the boundaries between phenomenon and context are not clearly evident. The case study method is congruent with the purpose of this study as its particular strength is its ability to allow for the description of both a contemporary phenomenon and its context.

Bogdan and Biklen (1982) suggested that the general design of a case study is best represented by a funnel. The beginning of the study is the wide end: the researchers consider the people and events that might be studied, judge the feasibility of the study site and data sources for their purpose, and then determine how they might proceed. Data are then collected and carefully reviewed in an effort to determine a direction for the study. Decisions are made on how time will be 
distributed, who will be interviewed, and what issues will be explored in depth. Old plans and ideas may be thrown aside as new ones are developed. The design and procedures of the study are continually modified as more is learned about the topic of the study. In time, the work develops a focus, and the data collection and research activities narrow to specific aspects of the study, such as sites, subjects, materials, topics, and themes. From broad, exploratory beginnings the researchers move to more directed data collection and analysis.

According to Bogdan and Biklen (1982), the case study itself structures the research, not preconceived notions or any well-defined research design. Therefore, the focus of this study was not entirely predetermined before entering the field. This investigation was guided by the following assumptions: collecting descriptive data is necessary in order to understand the meaning of events and interactions to program participants; observation of program participants in their natural setting is essential to describing their behavior; meaning and process of professional growth is crucial in understanding the elements of effective staff development programs; and the purpose of this qualitative research is to describe the staff development process rather than to evaluate or determine success or failure of the program. 
CONTEXT OF THE CASE STUDY

Selection of the study

During the fall of 1986, the Portland state University School of Education and the Lake Oswego School District entered into a collaborative program titled "Joint Ventures in Instructional Leadership." The program, which was implemented during the 1986-1987 school year, was designed to foster professional growth of teachers and administrators. Its purpose was to provide a model for educational partnerships, including the sharing of resources between a university and the public schools and the training of teachers and administrators in practices consistent with recent research in teacher and administrator effectiveness and instructional leadership.

In support of this program, the Portland state University School of Education agreed to provide resources to the Lake Oswego School District in the form of graduate students who desired field experience ranging from practicums and internships to research studies and doctoral dissertations. As a doctoral student specializing in staff development and desiring a fieldbased experience in that area, this author was selected by the University to participate in the program as a staff support specialist.

The position of staff support specialist afforded this investigator the opportunity to conduct a study 
capitalizing on a rather unusual event, the development and implementation of a new and uniquely designed staff development program. This author conducted an interview with the School District and University administrators in charge of the program to determine general information regarding the development of the program and the feasibility of the study. The study was then proposed and approved.

Setting of the study

The study was conducted in the Lake Oswego School District, a suburb of Portland, Oregon. The District is composed of 7 elementary schools, 2 junior high schools and 2 high schools. The total student population of the district is approximately 5,689, with 2,845 elementary students, 836 junior high students, and 2,008 high school students. The schools primarily serve students from middle income to upper income families.

\section{CASE STUDY DATA COLLECTION PROCEDURES}

A major strength of case study data collection is the opportunity to use multiple sources of evidence ( $y$ in, 1984). According to Yin, the use of varied sources of evidence allows an investigator to address a wide range of attitudinal and observational issues. However, the most important advantage of using multiple sources of evidence is that converging lines of inquiry can be developed, a 
process referred to as triangulation (Guba, 1978). This study employed a variety of data collection techniques to provide multiple measures of the same phenomenon, thereby increasing construct validity.

\section{Direct Observation}

Participant observation was the primary method of data collection utilized in this study. This method of observation was selected to allow this author the opportunity to perceive staff development activities from the viewpoint of someone "inside" the group rather than external to it. Yin (1984) argued that such a perspective is necessary to produce a true portrayal of a case study phenomenon.

The general sample included 34 teachers and 4 school administrators who participated in the staff development phase of the Joint Ventures Program. This investigator observed and took part in 11 staff development sessions, including 7 full days and 4 evenings of professional growth activities (see Appendix A). Activities and interactions of the 38 program participants were reconstructed in field notes taken during each session. This observer's role as a university staff support specialist allowed her to move unobtrusively among participants as they engaged in learning activities. She involved herself in group activities so that the interaction would not influence those being observed. 
Participants appeared to be comfortable with this process and accepted it as the norm.

This investigator participated in and observed other meetings concerning the Joint Ventures Program. On October 20, 1986, a two-hour school district administrative meeting was conducted by Bill Korach, the administrator in charge of directing the Joint Ventures Program, for the purpose of providing information regarding program goals, content, and implementation. Five elementary and 6 secondary school administrators, as well as another University staff support specialist, were in attendance. The meeting was audiotaped and later transcribed to provide additional support for the data base of the study.

A number of planning and debriefing meetings were also audiotaped and transcribed. Beginning in early September 1986, this researcher, another university staff support specialist, and the district administrator responsible for planning and conducting the program met several times to plan the content, organization, and implementation of staff development activities. Once the program began, the decision-making team met after each staff development session held during the 1986 school year to discuss activities and events that occurred and to plan for future sessions. The information collected during 
these meetings provided corroboratory evidence for field note data.

\section{Questionnaires}

Questionnaires were utilized throughout the study as an additional strategy to obtain data for analysis. An open-ended survey was administered at the closing of three of the seven day sessions. Program participants were asked to respond in writing to three questions:

1. What feelings and impressions could you share with us about this workshop?

2. How do you perceive the value of today's workshop?

3. What suggestions do you have at this point? These questions were designed to probe the attitudes and perceptions of program participants. The data were collected over a four-month period, allowing for changes in attitudes and feelings to emerge.

Another open-ended survey was administered during the second evening session of the program. Program participants were asked to make written responses to questions regarding their first "peer sharing" experience. Respondents addressed four questions:

1. What was the value of the peer sharing feedback you received?

2. How do you perceive your contribution to what others received? 
3. How would you evaluate your peer sharing session?

4. Given our program goals and our assumptions about peer sharing, how do you rate the value of this process as a means of improving instruction?

These questions continued the inquiry into program participants' perceptions.

During the final session of the program, participants were asked to make a written response regarding their opinions about the overall effectiveness of the program. Participants completed a program evaluation questionnaire, responding to open-ended questions regarding the strengths and weaknesses of the program.

During the fall of 1987, an open-ended questionnaire was designed to determine what changes had occurred in teachers' instruction practices as a result of program participation. The questionnaire was reviewed and validated by three experts on the Portland state University faculty. The survey, along with a cover letter (see Appendix B) and a stamped return envelope, was then mailed to the 34 teacher program participants in midNovember 1987. Thirty teachers responded to the questionnaire. 
Interviews

During the month of October 1986 , focused interviews were conducted with the District and University administrators responsible for initiating the Joint Ventures in Instructional Leadership Program. The purpose of the interviews, which were of an open-ended nature, was to obtain general background information about the program. Bill Korach, at that time Director of Special Projects for the Lake Oswego School District, was interviewed to determine the District's rationale for becoming involved in the program and how the program would be developed and implemented. Dr. Michael Carl, Head of the Department of Curriculum and Administration, was questioned on how the District/University collaborative partnership was formed and the nature of the school of Education's involvement in the program. The interviews were audiotaped and later transcribed to ensure an accurate record of collected data.

Additional open-ended interviews were conducted throughout the study. Several program participants were interviewed after each of the eleven sessions of staff development activities included in the program. The purpose of these discussions was to establish corroborative evidence for field note data and provide the investigator with additional insights into the occurrence of events. 
During the month of January 1988 , a subset of 8 Joint Venture program teacher participants were randomly selected to be interviewed to provide verification of responses given on the questionnaire designed to collect information about transfer of instructional strategies into the classroom. These interviews, which were conducted by telephone, also provided this researcher an opportunity to clarify questionnaire responses and make an in-depth probe into how and to what extent the instructional strategies learned in the Joint Ventures Program were incorporated into teachers' normal instructional repertoire.

\section{Video Tapes}

During the latter part of the program, participants were asked to videotape two lessons taught to students in the classroom. The purpose of this assignment was to provide accounts of teaching strategies to be used as a basis for "peer sharing." The first video tape demonstrated the teaching of a concept using any method the teacher deemed appropriate for instruction. The second taping required demonstration of a teaching method learned in the Joint Ventures Staff Development Program. Upon written request, 17 teachers loaned their second video tapes to this investigator. These tapes provided further evidence documenting which instructional strategies acquired through program participation were 
transferred into classroom teaching. This source of information, in addition to the questionnaire and telephone interviews on this topic, added to the triangulation of the study.

Documentation and Demographic Collection

Documentary information was collected throughout the course of the study. These data took many forms, such as: memoranda; agendas; announcements; program descriptions; seating charts; news clippings from the local paper; and District news releases. This collection of documentary data was used to corroborate and augment evidence from other sources.

Demographic information relevant to the study was obtained through the questionnaire administered in the fall of 1987. The age and number of years of teaching experience as well as the grade level and subjects taught by each teacher participant were documented. This information was used to reveal characteristics of the group and provide a framework for baseline data.

DATA ANALYSIS

Observation data relevant to describing the process of the Joint Ventures Staff Development Program and how participants perceived the program were assembled into chronological, narrative records that included transcribed interviews, observation field notes, documents, and 
interpretative asides recorded by this author in each setting. This integrated record, which also included written responses to questionnaires, provided multiple perspectives of single situations whereby the objectivity of the data could be judged. Issac (1971) asserted that the multiplicity of data souxces strengthen the validity of results.

Analysis included a variation of the constant comparative method formulated by Glaser and strauss (1967). This strategy includes the following steps:

1. Begin collecting data.

2. Look for key issues, recurrent events, or activities in the data that become categories for focus.

3. Collect data that provide many incidents of the categories of focus with an eye to seeing the diversity of the dimensions under the categories.

4. Write about the categories you are exploring, attempting to describe and account for all the incidents you have in your data while continually searching for new incidents.

5. Work with the data and emerging model to discover basic social processes and relationships.

6. Engage in sampling, coding, and writing as the analysis focuses on the core categories (Glaser, 1978). Although this method can be described as a series of 
steps, these procedures occur simultaneously, creating a complex, interactive method.

Design and analysis decisions were continually modified due to the flexible nature of the case study process. Consistent with descriptive paradigm, data were probed, analyzed, and coded according to emerging patterns. As categories were developed, patterns, repetitions, and contradictions within each category were noted. The result was a narrative account that described and explained the process of the Joint Ventures staff Development Program and how the program was perceived by participants.

Miles and Huberman (1984) suggested that analysis of qualitative data involves three concurrent flows of activity: data reduction; data display; and conclusion drawing/verification. Data reduction, a process which occurs throughout the study, includes selecting, focusing, simplifying, and transforming the raw observational data. This process aids in the organization of data so that final conclusioris can be drawn and verified. Data display is a systematized assembly of information that allows conclusions to be drawn. Data can be displayed in several forms, such as matrices, graphs, networks, or charts. Conclusion drawing and verification is the third component of this qualitative data analysis process. The purpose of this activity is to derive meaning from the reduced, 
displayed data. It involves the noting of regularities, patterns, explanations, and propositions contained within the data. Miles and Huberman (1984) described this process as interactive and cyclical.

In order to clarify the most important dimensions of this study, a conceptual framework was developed. This includes the key factors that determined the basis and direction of the study. The purpose of this framework was to provide a focus for the collection and analysis of data (see Figure 1).

A key issue that emerged from the study reguiring additional data collection and analysis was the transfer of newly learned skills and strategies into classroom instructional practices. Thus the question, "What skills and strategies, acquired through program participation, did teachers use and incorporate into their normal repertoire of teaching practices?" was developed. This question was addressed through the process of administering an open-ended questionnaire to teacher participants, conducting a random sample telephone interview, and observing video tapes of classroom instruction described earlier in this chapter.

Data analysis of the questionnaire began with categorizing and coding responses. Due to the open-ended structure of the questions, teachers were able to describe what new skills and strategies had been applied to 


\section{Background of the Study}

- The School/University partnership

The Staff Development Program

- Assumptions, goals, and objectives

- Program participants

- Teachers

- Administrators and others

- The planning process

- Program content and activities

- Day sessions

- Evening sessions

- Extended activities

\section{Program Outcomes}

- Perceptions of program participants

- Changes in instructional decision making

- Changes in classroom practices

Figure 1. Conceptual framework of the study. This figure represents the flow of the study from its broad beginnings to specific outcomes. 
classroom teaching, as well as how and to what extent the skills had been applied. The second step included describing the categories. Finally, the frequency of each category was determined and displayed.

Data analysis of the telephone interviews included a descriptive comparison between interview and questionnaire responses, providing a reliability check. Video tapes of 17 teachers delivering instruction in their classrooms were then analyzed to verify the transfer of instructional skills and strategies into classroom practice.

\section{RELIABI L ITY}

The test of reliability, as generally applied to quantitative research, is met when a later investigator repeats the study procedures and arrives at the same results. In qualitative case study research, since each case is unique, it is not possible to replicate the results of one case study by conducting another case study. Therefore, the goal of reliability in this type of research is to minimize the errors and biases in a study (Yin, 1984). Reliability was strived for in this study through careful documentation of procedures and employment of a variety of data collection strategies to provide multiple measures of the same phenomenon. 


\section{LIMITATIONS}

This study was subject to the following limitations:

1. Observational data were subjectively reduced.

2. The uniqueness of the case studied makes replication difficult.

3. The study was limited to one phase of the Joint ventures in Instructional Leadership Program.

4. Participant perceptions were a major source of data collection, and those perceptions must be accounted for in interpretation of the data.

5. The study described program content and training activities in general terms. Factors which may have influenced teachers' transfer of acquired skills into classroom practice, such as the specific nature of training activities and the extent to which they were used, were not documented.

\section{SUMMARY}

The purpose of this study was to describe the professional development process of teachers participating in the Joint Ventures Staff Development Program and determine what effects the program had on instructional decision making and teaching practices. The case study method was chosen as a research design appropriate to the purpose of the study. The study, which relies entirely on qualitative data, utilizes multiple sources of evidence to 
corroborate findings and develop converging lines of inquiry. These multiple measures create triangulation, increasing the reliability of research findings.

This chapter presented the rationale for employing the case study method. It further described the context of the study and provided an overview of the Joint Ventures Staff Development Program. Data collection procedures and the subjects specific to each procedure were discussed. An account of data analysis techniques was also provided. The chapter concluded with a discussion of the reliability and limitations of the study. 


\section{CHAPTER IV}

\section{RESEARCH FINDINGS}

\section{INTRODUCTION}

The purpose of this case study was to examine the professional growth process of teachers participating in the Joint Ventures in Instructional Leadership Staff Development Program and determine what effects the program had on instructional decision making and teaching practices. This chapter provides a full description of the program, including: its background; assumptions, goals, and objectives; the selection process and characteristics of teacher participants; the planning process; and the program's content and activities. In addition, the chapter presents findings pertinent to the following questions addressed in this study:

1. How did teachers perceive their professional growth experience?

2. Did participation in the program bring about any changes in how teachers made instructional decisions?

3. What skills and strategies, acquired through program participation, did teachers use and incorporate into their normal repertoire of teaching practices? 
A summary of research findings concludes the chapter.

\section{BACKGROUND OF THE STUDY}

During the fall of 1986 , the portland state University School of Education and the Lake Oswego School District formed a partnership to develop a professional growth program designed to encourage professors, administrators, and teachers to become full partners in the pursuit of knowledge about the teaching/learning process and its application to classroom instruction. The program, entitled "Joint Ventures in Instructional Leadership," was developed to provide a model for educational partnerships, including the sharing of resources between a university and the public schools, an inguiry-oriented approach to staff development, and the training of teachers and school administrators in practices consistent with recent research in effective teaching and instructional leadership. The program originated from the premise that both the Lake Oswego School District and Portland State University had potention for the reciprocal sharing of unigue resources as well as an opportunity to benefit from a collaborative partnership in the fostering of professional growth among professors, teachers, and school administrators. 
In support of the Joint Ventures partnership, Portland State University offered the specialized expertise of higher education by providing professors to participate in the professional development activities of the Lake Oswego School District. The University also made selected courses available within the District and encouraged qualified District staff to apply to teach University graduate courses. In addition, Portland state University agreed to provide resources to the school District in the form of graduate students who desired field experience ranging from practicums, internships, and projects to research studies and doctoral dissertations.

For its part, the Lake Oswego School District offered the expertise of selected teachers and administrators as speakers and consultants to Portland State education faculty. The District also offered a range of field-based experiences to the faculty and students in Portland State University's School of Education. In addition, the District expressed interest in developing opportunities to allow portland state doctoral students to conduct field studies and research in Lake Oswego schools.

The common thread between the University and School District was Bill Korach, Lake Oswego High School principal on special assignment leave and the 1985-86 Administrator in Residence who was spending his second 
year as a member of the Portland state university educational administration faculty. He was due to return to Lake Oswego High School in the fall of 1986 to resume his duties as principal. However, as part of the Joint Ventures partnership agreement, he was retained by Portland State to teach three evening classes per term during the 1986-87 school year as well as maintain a minimum of four office hours per week to meet advisement expectations. At that time, Korach was also appointed by the Lake Oswego School District as Director of Special Projects, in charge of directing the Joint Ventures Program within the District. The cost of his salary was shared by the University and School District. In early September 1986, Portland State University provided two full-time graduate assistants, Nancy Nagel and this author, to aid Korach in the development and implementation of the Joint Ventures Program. Nagel was a former primary and special education teacher who had several years of experience in the field of teacher education as an instructor and student teacher supervisor. This author, also an experienced teacher educator and instructional supervisor, had formerly worked as a staff development and curriculum coordinator and had a number of years of experience as an intermediate grade teacher. A broad range of educational experiences and expertise was brought to the program by Nagel, this author, and Korach, 
who together formed the Joint Ventures Leadership team. This team worked throughout the 1986-87 school year to shape, coordinate, and carry out the various phases of the program.

The Joint Ventures in Instructional Leadership Program included the following phases, which were implemented concurrently during the 1986-87 school year:

1. Afternoon and evening classes were taught within the District by Korach and this writer in an effort to make opportunities for professional growth more readily available to Lake Oswego staff.

2. Three separate two-day instructional improvement workshops, primarily involving secondary teachers, were conducted within the District by this author.

3. Several Lake Oswego teachers and administrators taught graduate education courses at Portland State University. This phase of the program was coordinated by Korach.

4. Several Lake Oswego teachers and administrators made presentations to selected Portland State University classes. In addition, a number of professors made presentations to Lake Oswego classes. Each presenter received an honorarium paid by the University. This phase of the program was coordinated by Nagel.

5. An experimental staff development program designed to foster instructional leadership within the 
Lake Oswego School District was implemented. This program, which focused on the teaching of thinking, was conducted by Korach and supported by Nagel and this author.

The last phase described above was the heart of the Joint Ventures in Instructional Leadership Program and the focus of this case study.

THE STAFE DEVELOPMENT PROGRAM

An experimental program designed to foster professional growth of teachers and administrators was conducted in the Lake Oswego School District during the 1986-87 school year. Thirty-four Lake Oswego teachers and 4 administrators participated in the program, which included classes in learning and instructional theory, techniques of peer sharing, instructional strategies and models of teaching, and approaches to the teaching of higher order thinking skills.

The Joint Ventures in Instructional Leadership staff Development Program was conceived by Bill Korach, Director of Special Projects for the Lake Oswego School District. In addition to developing a conceptual framework for the program, he organized and conducted class sessions. Director Korach was supported by two Portland state University graduate students, Nancy Nagel, and this 
author, who assisted with program planning and implementation.

The staff development program included 7 full days and 4 evenings of instructional training spaced over a period of 30 weeks from October, 1986 through April, 1987 (see Figure 2). The School District released teachers from their classrooms to attend the day sessions. Each program participant received three graduate credits from Portland State University for each term during the 1986-87 school year, totaling nine credits. The Lake Oswego School District paid tuition for each participant through the Division of Continuing Education, which kept the overhead costs and returned the remainder of the money to the Portland state School of Education. In turn, the money was remitted to the School District to pay for the release-time costs of substitute teachers.

Assumptions, Goals, and Objectives

The Joint Ventures staff Development Program, having school improvement as its ultimate aim, was based on five major assumptions about change:

1. Change is a process rather than an event. Meaningful change is a process of gradual growth, the final form of which cannot be predetermined.

2. Change must be understood in terms of what happens to individuals. Understanding how individual 


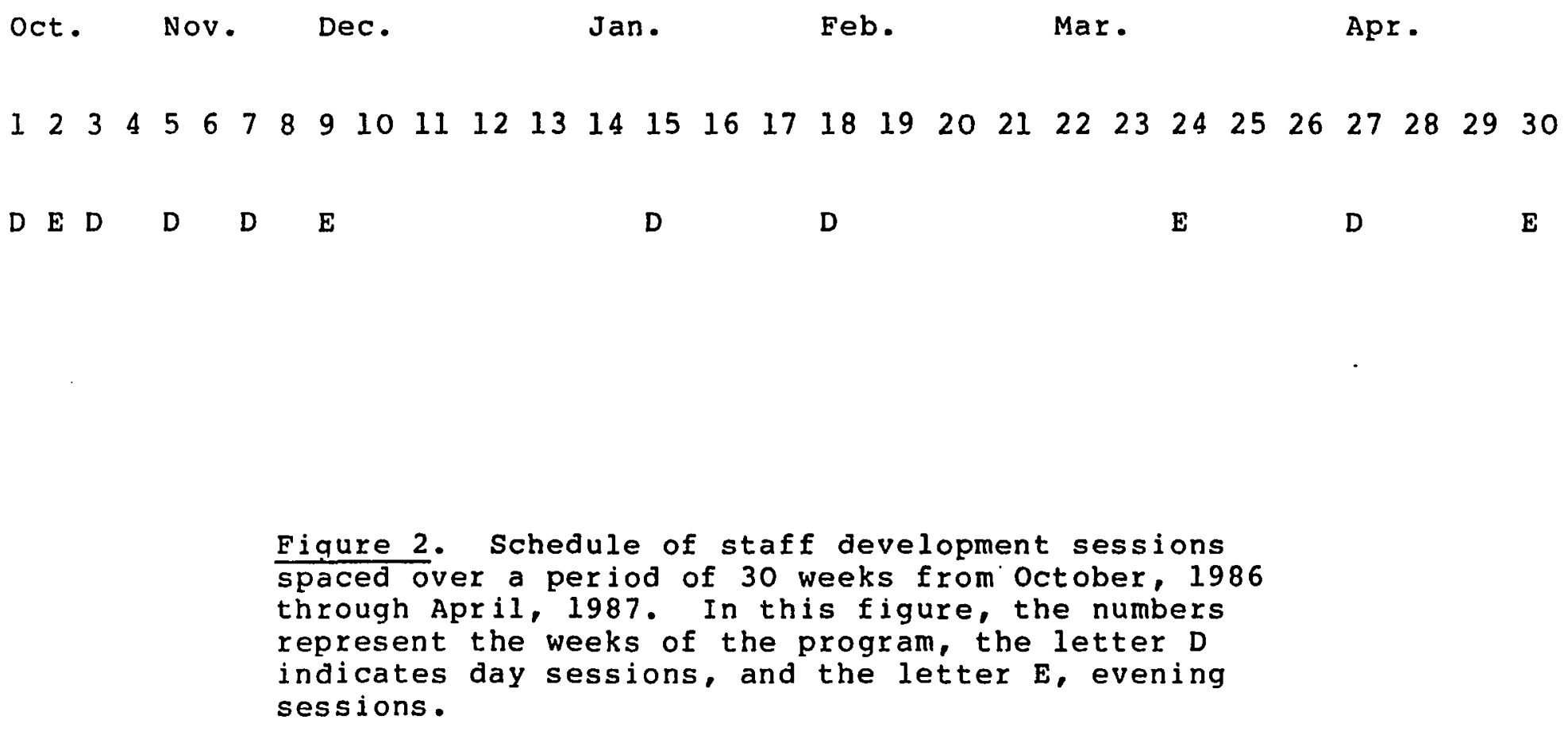

Fiqure 2. Schedule of staff development sessions spaced over a period of 30 weeks from October, 1986 through April, 1987. In this figure, the numbers represent the weeks of the program, the letter $D$ indicates day sessions, and the letter $E$, evening sessions. 
teachers and principals respond to an innovation is critical to the change process.

3. Change for individuals is a highly personal experience. The personal perceptions, feelings, and frustrations of individuals are a part of the change process.

4. Change by individuals entails developmental growth in terms of their feelings and perceptions of the innovation and their skill in using the innovation. It is possible to diagnose the perceptions and feelings and skills in the use of innovations.

5. The likelihood of worthwhile change is greatest in a nonevaluative setting that fosters ongoing professional sharing.

The Joint Ventures Staff Development Program offered a unique approach to the change process in that it was oriented toward intellectual inquiry rather than predetermined solutions or established frameworks for instruction. Not only did teachers acquire knowledge about effective instruction and research on teacher effectiveness, they were encouraged to experiment with applications of that knowledge to their particular teaching assignment. Thus, the question of when and how to apply research findings in the classroom became the focus of continued professional sharing. This approach 
emphasized the process of change rather than any set of specific changes.

The program was structured to meet the following goals:

1. To reinforce the perspective that while there are many effective skills, strategies, and models for good teaching, there are no blueprints.

2. To establish a common base of understandings about teaching through a collaborative learning experience, focusing on the teaching of thinking.

3. To enhance professional decision making by emphasizing the role of the teacher as scholar-researcher.

4. To participate in the sharing and exploration of instructional alternatives and opportunities in a collegial, nonevaluative atmosphere.

5. To encourage instructional leadership through continued professional sharing.

The purpose of the program was threefold: to build a common base of understandings about the teaching/ learning process focused on the teaching of thinking; to train teachers in methods based on recent research in teaching effectiveness, including approaches to the teaching of higher order thinking skills; and to establish a norm of instructional sharing among teacher participants. These objectives were based on an emerging School District philosophy emphasizing the teaching of 
thinking as a cross-curricular endeavor that extends through all grade levels. This change in philosophy would ultimately require changes in the attitudes, beliefs, and teaching practices of Lake Oswego teachers. The Joint Ventures staff Development program was designed as a first step in effecting these changes in that it proposed to develop a cadre of teachers representing all grade levels and curricular areas. It was hoped that these teacher leaders would begin to incorporate the teaching of higher order thinking skilis into classroom practice and facilitate instructional sharing within their school buildings.

Program Participants

Teachers. A select group of 34 teachers participated in the Joint Ventures staff Development Program. Candidates for the program were selected by their building principals. Teachers were recommended for participation on the basis of a combination of factors, including their proven expertise in teaching, their current influence as instructional leaders, and their potential to lead and influence others. These recommendations were made according to principals' perceptions of teacher attributes rather than any set of specific criteria. In early september 34 teacher nominees were informed of the program and invited by the school District to participate. Thirty of these teachers agreed 
to take part in the program. Four teachers declined to participate and were replaced by alternate candidates. Teachers chose to participate in the program for a variety of reasons. When asked why they chose to become involved in the program, the majority of the teachers responded that they desired an opportunity to find new ways to increase student learning and participation. other popular responses indicated teachers' wishes to comply with their principal's invitation and recognition of Korach as an excellent instructor. Additional reasons for participation included a love of learning, the need for a challenge, and curiosity. Teacher participants represented all major curricular areas and grade levels, including 6 teachers from each of the 2 junior highs. Six of the elementary schools were each represented by 2 teachers; the seventh elementary school was represented by one teacher. A district level Talented and Gifted teacher also participated in the program (see Appendix C).

The teacher group was representative of Lake Oswego School District norms for age and years of teaching experience. The average age of the group, which included 21 females and 13 males, was 40 years. Years of teaching experience ranged form 8 to 28 , with an average of 15 years. 
Administrators and Others. All Lake Oswego District administrators and elected members of the school board were welcomed to participate in the Joint Ventures Staff Development program. Several of these individuals took part in some of the sessions. Four administrators participated fully in the program, including a high school principal and vice principal and 2 elementary school principals.

\section{The Planning Process}

In early october, before staff development sessions began, the leadership team met together several times for the purpose of program planning. During these in-depth planning sessions, the team reviewed program goals and content and discussed a timeline for staff development activities. The team also explored alternative approaches to the implementation of what they considered to be important elements of the program, such as the organization and delivery of content, a "peer sharing" process, and follow-up assistance for program participants.

Several decisions were reached as a result of these meetings. First, all decisions made at that time would be tentative, based on the team's recognition that future changes in plans would most likely be necessary to accommodate individual needs of program participants, the nature of the staff development group, input from the 
group, and unforeseen changes in time schedules. The team decided, in order to effectively deal with these unknown variables, that program planning would be a focus of team meetings held throughout the year. Second, the team established a beginning point and set a direction for the delivery of program content. Bill Korach would conduct staff development sessions; Nancy Nagel and this author would participate in each session to facilitate learning activities. Instruction would be adjusted as necessary, based on observations of the leadership team and input from the learning group. Third, the team developed a timeline for program activities. Fourth, it was decided that "peer sharing" would be done in groups of three based on observations of video tapes of classroom instruction. Each program participant would be responsible for producing two video tapes for the purpose of "peer sharing." The first tape would demonstrate the teaching of a concept; the second tape would demonstrate the use of an instructional model or strategy that promoted student thinking. Details of the "peer sharing" process would be determined during future planning meetings. Finally, the leadership team agreed that they would be responsible for providing follow-up support for teachers as they attempted to use newly learned skills and strategies in their classrooms. It was decided that korach would provide follow-up assistance at the two high schools, this author 
would support teachers at the two junior high schools and one elementary school, and Nagel would work with teachers in the remaining five elementary schools. Because the team felt it was important to communicate planning decisions to school administrators, it was decided that follow-up assistance for teachers would not begin until after a meeting with administrators, which was scheduled for November.

In mid-November the team met with District administrators to review program goals and content and discuss possibilities of how Joint Ventures participants might be used to facilitate instructional improvement at the building level. Korach, who directed the meeting, emphasized that the intent of the Joint Ventures Program was not to produce a cadre of teacher trainers, but to develop a group of instructional leaders who could share their knowledge and expertise in the area of teaching thinking with other teachers in their buildings. Korach suggested that each school had the option of utilizing Joint Ventures participants in building-level, staff development activities as was deemed appropriate by building administrators. Administrators were informed that the leadership team would be available to assist in the planning and implementation of school-based staff development activities. Korach also shared the team's 
plan to provide ongoing instructional support for Joint Ventures participants within their school buildings.

The leadership team met after each staff development session held between october and December for the purpose of planning subsequent sessions. Decisions regarding lesson content and learning activities were made based upon the team's review of written feedback provided by program participants at the end of each class session. During these planning meetings, the team also prepared to begin follow-up assistance for teachers within their school buildings.

Unforeseen changes in Korach's role within the School District necessitated modifications in the planning process as well as the program itself. In January, the Superintendent of the Lake Oswego School District resigned from his position. As a result, the Assistant Superintendent was named Acting Superintendent, and Korach was appointed Acting Assistant Superintendent. The responsibilities of this new role were added to korach's existing commitments to Portland State and the Joint Ventures Program, considerably increasing the demands on his time. Soon after Korach's appointment, the leadership team met to discuss modifications in the staff development program that would be necessary to compensate for the Iimited amount of time that korach would be able to devote to the program from that point forward. It was decided 
that team planning would no longer occur on a regular basis and that follow-up assistance for teachers, which was just getting under way, would not take place. From January forward, staff development sessions continued as scheduled (see Figure 2). Assistant Superintendent Korach assumed full responsibility for the planning and instruction of these sessions. Nagel and this author continued their support by attending staff development sessions as well as fulfilling their responsibilities to other phases of the school/university partnership program. Team communication became limited to brief discussions before or after staff development sessions as a result of Korach's increased workload as well as his decision in February to begin the process of vying for the open position of superintendent. In April, with two staff development sessions remaining, Korach was hired as superintendent of the Lake Oswego School District.

\section{Program Content and Activities}

The Joint Ventures in Instructional Leadership Staff Development Program included 7 full days and 4 evenings of instructional training in learning and instructional theory, techniques of peer sharing, instructional strategies and models of teaching, and approaches to the teaching of higher order thinking skills. In addition to participating in the 11 staff development sessions, 
program participants completed independent activities that were assigned to reinforce learning (see Appendix D). Appendix E provides a full description of program content. Day Sessions. Day sessions began at 7:30 a.m. with a 30-minute period of informal activity. As program participants arrived to class, they found the day's seating assignments posted on the tables at which they would sit in groups of four. After locating their stations, which rotated from session to session to facilitate interaction within the group, the majority of class participants helped themselves to coffee or tea and formed small groups to discuss topics relating to school and the community. Others used this time to review class materials or assignments.

At 8:00 Bill Korach called the class to order and, after a few introductory remarks, began the day's instructional activities. The first activity of each session was a review involving small group discussion of prior learning. Given handout materials identifying key concepts, participants were asked to recall definitions and give explanations of materials learned in previous sessions. After approximately 20 minutes of "table sharing" in cooperative learning groups of four, the class was brought together as a whole to summarize their understanding of the concepts reviewed. 
Instructional activities following each review

included presentation of theory and/or teaching

strategies, modeling, practice, and feedback. The most

frequent mode used to deliver new content was a short

presentation given by Korach. Lectures were accompanied

by handout materials that provided class participants with additional data, including models of the information

presented. Other means of presenting new information and

modeling to the class were through the use of audio and

visual tapes and guest speakers. Delivery of new content

was invariably followed by class discussion and

cooperative learning activities allowing participants to

apply what they had learned. During this time Korach,

Nagel, and this author monitored learning groups and

provided feedback to participants in response to their

efforts. After small group activities were completed, the

class was called together to share their learning

experiences. Thus, an instructional pattern that included

varied presentations of new content and modeling, small

group practice, feedback, and class discussion was

repeated throughout each day session.

Insiructional activities were interspersed with a mid-morning break, an hour lunch period, and an afternoon break. The morning break commenced at about 10:00 a.m., shortly after the School District's cooks entered the room with large trays of freshly baked cinnamon rolls or 
muffins and an assortment of fruit and drinks. This event was consistently cheered by the class. At noon the cooks again arrived to serve a luncheon provided by the

District. During the lunch hour class participants served themselves to a variety of food and drink, then gathered in groups at tables in the classroom or outside on the grass to eat and converse. After lunch the class reconvened for a two-hour instructional period that included a brief afternoon break.

Shortly before class was dismissed at 3:00 p.m.. participants were asked to provide written feedback on the day's session, including their feelings and impressions, their perceived value of the workshop, and suggestions for future sessions. These formative evaluations, in addition to observations made throughout the day by the leadership team, were used as a basis for planning subsequent sessions that would meet the needs of class participants. Evening Sessions. The format and content of the four two-hour evening sessions varied throughout the program. The first two sessions focused on the concept of peer sharing and discussion of how the process would be carried out by class participants. The third session was designed to provide participants with individualized help on an assigned project. The last evening session, which concluded the program, was devoted to a class discussion of the program's effectiveness, its strengths and 
weaknesses, and suggestions about how the program might be carried out in the future. During this session a written summative evaluation of the program was also completed by class participants.

Extended Activities. Three major independent activities were assigned to class participants during the course of the program. One of the extended activities included the reading of the class textbook, Models of Teaching (Joyce and Weil, 1983). Chapters of the text relevant to class learning activities were assigned after each day session. Another extended activity involved the development of an instructional analysis packet whereby class participants designed a detailed, conceptual framework for an instructional unit. The third extended activity required participants to be involved in the process of two peer sharing sessions.

The peer sharing process, designed to promote collegial sharing and exploration of instructional strategies based on nonevaluative observations of classroom teaching, included three phases. First, it required each class participant to develop a lesson plan and to videotape the teaching of that lesson to their class. The second phase necessitated that participants, in selected groups of three, exchange their tapes along with lesson plans and written requests for feedback on the lessons. After tapes were viewed and feedback was 
formulated by members of the group, the third phase of the process was implemented. This involved a sharing session where each member of the group took a turn being the recipient of feedback from the others. The times and places of these sessions were coordinated within each group to facilitate scheduling.

Each class participant was involved in two peer sharing sessions. During the first session, which occurred in November, participants worked in groups, consisting, on the most part, of individuals from the same school building, to help establish a level of comfort within the groups. These groups shared video tapes demonstrating the teaching of a concept using any instructional method deemed appropriate for the lesson. The second peer sharing session, which took place in February, involved groups consisting of individuals from different school buildings and grade levels to reinforce cross-curricular and cross-grade level interaction. The videotaped lessons shared within these groups focused on the use of methods for teaching thinking. Although the two peer sharing sessions varied in focus and group membership, they entailed the same process of collegial shar ing.

The preceding pages of this chapter presented a full description of the unique characteristics of the Joint Ventures in Instructional Leadership Program. The 
following presentation of findings represents the analysis of data from multiple sources in response to the three research questions addressed in this study. It begins with a description of teachers' perceptions of their professional growth experience.

\section{PERCEPTIONS OF PROGRAM PARTICIPANTS}

The first research question under consideration is "How did teachers perceive their professional growth experience?" In reference to this question, data comes from four major sources, including workshop feedback from the first, second, fourth, and fifth day sessions of the program, field notes, peer sharing feedback, and program evaluations.

Before data are presented, one issue warrants discussion. In response to the above research question, the subsequent narrative presents findings in terms of teachers' perceptions. However, these findings are based on data gathered not only from teacher participants, but also from the four administrators who participated in the Joint Ventures program. The anonymous nature of the data collected from the group as a whole made it impossible for this author to distinguish between teachers' and administrators' viewpoints. Therefore, the reader of this study is advised that all program participants are defined 
as teachers for the purpose of addressing the first research question as follows.

Data from workshop questionnaires, field notes, and program evaluations indicated that a clear majority of program participants viewed their instructional leader in a positive light. Bill Korach was viewed as an "excellent teacher who really knew his stuff." Participants were impressed with Korach's knowledge of the subject matter and the organized fashion in which it was presented. Teachers also valued the "relevant, useful handout materials" that were selected to accompany instruction. For example, one teacher commented, "I very much appreciate the amount of time, energy, and expertise that has obviously gone into the preparation of materials and the planning of lessons."

Many teachers felt that Korach's teaching style was very effective in promoting learning and stimulating interest. Participants liked the variety of means by which material was presented and appreciated Korach's ability to monitor learning and adjust instruction according to the needs of his students. The pace of instruction was generally described as "good." However, some individuals complained at times that it was "somewhat slow" or "too brisk." Teachers especially enjoyed working within cooperative learning groups established by Korach for the purpose of review and practice. One teacher 
remarked, "I like the small group activity and involvement allowed for each piece of instruction as we add to, refine, and synthesize a common base of knowledge." According to teachers, Korach's greatest instructional strength was that he "practiced what he preached." Not only did he provide "effective modeling" of teaching strategies during instruction, but he also incorporated a variety of those strategies into his own teaching practices. This provided teachers with many opportunities to visualize and experience the strategies they were expected to practice and apply to instruction. Participants found this modeling process to be "extremely effective." For instance, one teacher commented, "Much of the value of the program is in the modeling provided. Most people with whom I've talked in this class have introduced strategies in their classrooms that they have seen Bill use." Another teacher, reflecting the views of many, described Korach as "an excellent model for exciting teaching."

Not only did participants view Korach as an oustanding instructor, they also saw him as an inspiring leader. Most were impressed with his "charismatic and entertaining style." Many admired his "sense of vision" as well as his sense of humor. Korach was described by one teacher as having "the insight of Ghandi and the wisdom of the Bhagwan." 
Teachers felt that a "very comfortable and challenging class climate" was fostered by Korach's. "willingness to be open, to experiment, and to risk." One teacher remarked, "Bill encouraged a free and open exchange of ideas. He accepted any and every response from the group. Each person was made to feel important." Another individual expressed similar sentiments. "This is the atmosphere I would wish for in every Ed. class. I feel I can ask questions and contribute ideas easily and comfortably." It was also believed by some that Korach's "accurate sense of audience" and his "sensitivity to the needs of the group" promoted a positive learning envi ronment.

The collegial, cooperative class atmosphere fostered by Korach was strengthened by the willingness of most participants to share and accept each other's ideas. For example, one teacher perceived her peers as "a high powered group of people willing to listen and consider different opinions." Another instructor, expressing a similar view, remarked, "We were a very congenial, collegial group of bright, creative people. Class interaction was open and growth producing. I value the mutual respect we gave each other."

Teachers enjoyed class interaction and valued the comradeship of their peers. One teacher captured the feelings of many by saying, "The sharing of staff ideas 
was super. I met many wonderful people through this experience and gained insight into others' teaching assignments." Participants especially favored the rotating seating arrangement that allowed them to work within different cooperative learning groups during each class session. One instructor commented, "I really liked the flexible groupings. I had the opportunity to work with many people from different schools, grade levels, and subject areas."

Peer sharing, an extended class activity involving groups of three, provided yet another context for teacher interaction. Data from field notes and the peer sharing questionnaire indicated that all of the teachers in this study found the peer sharing process to be a valuable learning experience. They viewed the process as "an effective tool to improve instruction as well as reinforce good instruction." A strong majority of the teachers reported that they gained new insights into the teaching process as a result of receiving specific feedback from their peers and discussing alternative approaches and strategies to instruction. The comment below illustrates this point:

After sharing, my peers really had me feeling great, especially since they pointed out strong points of my lesson that I hadn't even valued or noticed. I saw my teaching from a different viewpoint. It was a pleasure to see master teaching and discuss choices that were made in format, style, and techniques. We shared insights and techniques that we all could use. 
This allowed for group discussion that was open, fun, and thoughtful. Our session was stimulating and informative. All three of us felt very good about sharing and enjoyed the experience of trying new methods/ideas in our subject areas. I think we all left with very positive feelings and understandings of each others" styles and subjects.

Another teacher enthusiastically expressed similar sentiments about her learning experience, reflecting the views of many other instructors.

I felt two extremely valuable aspects of the experience were the chance to actually observe the methods/strategies some of my colleagues use with the same subject matter I teach and the resultant discussion of alternative strategies and points of view on the content. Teachers discussing instruction is exciting! My contribution was to respond to the questions asked by my two partners with specific suggestions of other possible approaches--not necessarily better, but different ways of structuring the lesson. Our session was excellent. We were all accepting and respectful of one another's suggestions and comments without being hesitant to explore ideas and/or disagree.

A clear majority of program participants reported peer group interaction to be a "very positive" experience. Since the peer sharing process included the exchange of formative rather than evaluative feedback on instruction, most teachers perceived the experience as "comfortable and relaxed, as the nonevaluative atmosphere allowed for a free exchange of concerns and information." Many teachers described the sharing process as "congenial," "open," and "nonthreatening." They felt that their peers were "trustworthy," "sensitive," and "supportive," reflecting attitudes of "mutual respect." One teacher captured the 
sentiments of many by saying, "I came away with a renewed feeling of collegiality."

In contrast, a few teachers (5) perceived their peer sharing experience in a less favorable light. These individuals reported that the "comfort level" felt within their groups was not high enough to support open and honest feedback about instruction. For example, one teacher commented, "I didn't get a lot. I didn't give a lot. I don't think that one meeting is enough to build the trust level to the point where people are comfortable enough to really interact." Another teacher remarked, "The session was a testing of the water's temperature. A lot of time was spent checking perceptions and reassuring each other of skills and abilities." She went on to say that she thought a group must meet several times to eliminate the "reassuring time" and get right to the task of coaching.

Other concerns expressed about the peer sharing process in general included problems with the mechanics of videotaping, and the "limitations of the technology to capture student interaction and the feeling tone of the class." The time factor involved in the process of planning, taping, and sharing was also a concern to some. one teacher mentioned that her peer sharing session alone took almost two hours of time. She felt that the "time 
problem" would need to be addressed if peer sharing was to become an ongoing process.

A time problem of a very different nature, involving program scheduling, was reported by slightly over half of the teachers. They felt that too much time elapsed between class sessions. Reflecting the views of many others, one instructor remarked, "The time span between meetings sometimes made it hard to pick up and go. We needed more frequent, ongoing contact. It's too long to wait for a month to be involved." Another teacher expressed similar sentiments. "It was difficult to get into the subject matter after so much time had passed. I lost my reference point and things got fuzzy."

Teachers differed over a separate but somewhat related issue regarding the program's length. Several participants felt that the program was stretched over too long a time frame. As a result, interest waned, learning faded, and enthusiasm diminished. On the other hand, some teachers thought that the program was not long enough. One individual complained that more time was needed to allow him the opportunity to thoroughly integrate skills into his classroom. Another teacher voiced a similar concern. "I felt frustrated because we ran out of time before I had a chance to really use all this stuff in my class." 
The ability to "use all this stuff" was an issue of concern expressed by teachers after the first session of the program. Many participants complained that they felt "somewhat overwhelmed" by the volume of instructional theory that had been presented in class and "eagerly awaited" the opportunity to learn how the information could be incorporated into specific lessons. One teacher remarked, "I'm hoping that this will all make sense to me as we get to try some hands-on activities." Another instructor said, "I look forward to applied examples of the theory. I'm anxious to begin application and practice."

In response to teacher feedback from the first class, the second day session was planned to provide participants with more application level activities. As a result, teachers left the second session feeling "much more comfortable" in that they were given "more concrete data and techniques that could readily be applied to teaching." For example, one teacher commented, "I can now see where the theory and terminology fits in and can begin to apply it."

As the class continued to meet on a biweekly basis over the next two months, few teachers expressed any concern regarding application. In fact, many participants reported that they had used, in their classrooms, some of the strategies that they had learned and practiced during 
class sessions. One teacher reported, "I'm already

incorporating some of these ideas and strategies into.my new units." Another instructor commented, "I'm aware of several different teaching models now and am using them in my teaching."

After an eight week break between sessions, however, well over half of the participants returned to class voicing concern about the application of teaching strategies to classroom practice. One teacher expressed the views of many other participants:

At this point in the program, I am concerned about the infusion of the thinking models into my teaching methods. Though everything makes sense when I see and practice the models in our class, I get taken aback by the application of these in my own classroom.

Another instructor commented, "I'm experiencing frustration due to trying to figure out how to apply the models in my classroom. I'd like to do more sharing among the participants of ways they have applied the things we've learned in their classrooms." Still another teacher voiced similar a concern:

I continue to feel a bit overwhelmed by the tremendous amount of terminology and the great variety of models presented. It will take me a long time to make sense of it all. I am beginning to realize, with only two sessions left, that there is not enough time for proper closure and implementation. That worries me.

In addition to the above concerns, teachers were disappointed to learn that the leadership team would not be providing them with follow-up assistance in their 
classrooms as was originally planned. One teacher remarked, "I am extremely disappointed that there will be no work with individual teachers in their classrooms. That experience is what would best bring together everything we have learned." Another teacher expressed her dismay with the situation, saying, "I am concerned about follow-up and am disappointed that there will not be any classroom observation/interaction with Bill, Christene, or Nancy. Their feedback would have been very helpful."

Despite the various concerns felt by individuals over the course of the program, all participants perceived their overall staff development experience as rewarding, stimulating, and enjoyable. One teacher captured the feelings of most participants:

I feel that my participation in Joint Ventures was a very positive experience. I thoroughly enjoyed the class time and getting to know so many teachers from all levels. Many of the ideas presented in class have become part of my regular class activities and have given my teaching a boost.

Another teacher reflected the views of many:

This program has had a profound effect on my teaching and students. I gained much from interacting with secondary as well as elementary teachers. My enthusiasm has increased, as well as my desire to continue to improve. Joint Ventures was a very positive experience! 
Summary

Joint Ventures Program participants viewed their overall professional growth experience in a very positive light. They saw their instructor not only as an inspiring leader, but an excellent teacher who fostered a comfortable, yet challenging, learning climate. Teachers also appreciated the cooperative, respectful attitudes of their peers and enjoyed class interaction.

The peer sharing activity proved to be a valuable learning experience for all class members. Most teachers perceived their sharing experience to be congenial and nonthreatening; however, a few expressed concern over the comfort level felt within their peer groups. other concerns expressed by participants over the course of the program dealt with issues regarding program scheduling and the application of newly learned teaching strategies to classroom practices.

\section{CHANGES IN INSTRUCTIONAL DECISION MAKING}

The second research question to be addressed is "Did participation in the program bring about any changes in how teachers made instructional decisions?" Data related to this question were obtained through two sources, including a questionnaire developed for this study which included the question and follow-up telephone interviews 
which were conducted to provide verification of responses given on the questionnaire.

Al1 30 teachers responding to this question reported that their participation in the Joint Ventures Program had brought about changes in the way they made choices about certain aspects of the instructional process. The reported changes fell into two categories, including the planning and organization of content and the use of instructional strategies. A strong majority of teachers described changes that fell into both categories.

All reported changes occurring in the area of content planning and organization reflected teachers' tendencies to take a more conceptual approach to the development of instructional units. One teacher illustrated this point by saying, "I am now much more concerned about teaching concepts rather than facts. When I plan my units, I carefully map out these concepts so I have a conceptual framework for my lessons." Another teacher expressed a similar view. "I am more mindful of concepts and their relationships. As I plan my units, I pay more attertion to developing a schema so I can see how the parts relate to the whole." still another teacher explained that the "concept mapping" of her content helped her to "build stronger bridges between lessons and units." Reported changes in the way teachers made decisions about the use of instructional strategies were twofold. 
First, teachers reported the use of "a broader range of instructional strategies" in their classrooms. One teacher commented, "I now have a menu of strategies from which to choose. I make a conscious effort to vary the techniques that I use." Another instructor echoed the comments of many others. "I now consciously consider the use of different strategies. When I plan for instruction, I think of the alternatives and then select and use the method that I've decided is most appropriate."

According to teachers, participating in the Joint Ventures program not only resulted in the use of an expanded instructional repertoire, but also influenced the emphasis of their instruction. This emphasis, which was placed on the teaching of thinking, resulted in a shift to teaching strategies designed to "promote student thinking and interaction." As one teacher put it, "I do more group activities that require students to be active manipulators of information rather than passive receivers." Another teacher commented, "I now use strategies that increase the mental processing of my students. I involve them more by getting them to think, predict, and wonder. Group learning and partner sharing is now a regular part of my program." Many other teachers reported that they were "more inclined to use cooperative learning strategies" in their classrooms. 
Summary

According to the 30 teachers responding to the questionnaire, participation in the Joint Ventures program brought about changes in their approaches to the planning and organization of content and the use of instructional strategies. Reported changes in the area of content planning and organization involved teachers' restructuring of instructional units to provide a conceptual framework for teaching. Reported changes in the way teachers made decisions regarding the use of instructional strategies resulted in the application of a broader range of teaching strategies. In addition, teachers increased the use of strategies designed to promote student interaction and higher order thinking. The majority of teachers reported changes in both areas.

SKILLS AND STRATEGIES USED AND INCORPORATED INTO CLASSROOM TEACHING PRACTICES

The third research question under consideration is, "What teaching models and strategies, acquired through program participation, did teachers use and incorporate into their normal repertoire of instructional practices?" In reference to this question, data came from three sources. These sources include a questionnaire developed for the the purpose of investigating this issue, follow-up telephone interviews, and video tapes of classroom 
instruction demonstrating the incorporation of teaching models and strategies into instructional practices. . Before data are presented, one issue relating to this question warrants consideration. Although the terms concept mapping, problem solving, expressive learning, and metacognition are generally referred to as learning strategies, teachers participating in the Joint Ventures Program came to refer to them as teaching strategies. This terminology is used in the following presentation of data.

Through participation in the Joint Ventures Program, teachers learned seven models of teaching that may be used to promote student thinking. When asked if any of these teaching models had been applied to classroom instruction, 29 of the 30 teachers responding to the questionnaire reported having used one or more of the models. The most frequently mentioned model employed was cooperative learning (19 responses). Many teachers also reported using concept formation (13 responses) and concept attainment (12 responses). Only a few teachers indicated they had used advance organizers (4 responses), direct instruction ( 3 responses), inquiry training ( 3 responses), or the synectics model (2 responses).

As a result of program participation, teachers also acquired knowledge about four major teaching strategies that can be used to enhance student thinking. All 30 
teachers responding to the questionnaire reported having employed one or more of these strategies in their classrooms. The strategies most frequently mentioned were concept mapping (18 responses) and problem solving (16 responses). Five (5) teachers indicated that they had used expressive learning and 2 teachers reported they had employed metacognition.

The extent to which the subjects of this study utilized the teaching models and thinking strategies in their classrooms varied according to the individual teacher and the circumstances under which these instructional methods were used. Since the majority of instructors reported having applied more than one teaching model or strategy, most found it difficult to "put a finger on exactly how often" each model or strategy was used. However, these instructors reported "frequent" use of the skills. Others indicated that they employed the teaching models and/or strategies on an occasional basis. One teacher, reflecting the views of many instructors, commented, "It's hard to sort them all out. I guess I could say that I use them on a regular basis, but only as needed and appropriate to lesson content and desired outcomes."

The "sorting out" process may have been difficult, in part, because most teachers did not use the teaching models or strategies in their "pure" form. In fact, 24 of 
the 30 respondents indicated that they had applied the models and strategies in their classrooms in a different manner than the way they were learned in the Joint Ventures program. When asked how the models and strategies were used differently, the majority of teachers said that they had modified or combined them to suit their teaching style, the needs of their students, and/or time constraints. For example, one teacher remarked, "I have not taken a pure teaching model or strategy and used it in my classroom. Rather, I have synthesized these and drawn upon them all in a more holistic way." Another instructor expressed similar sentiments. "I mix and match the models and strategies as needed. I'll often modify them according to time limitations, the attention level of my students, or my own flair for teaching."

videotaped demonstrations of classroom instruction delivered by many of the subjects of this study provided additional evidence supporting the above findings. of the 18 videotapes reviewed by this researcher, only 3 showed the use of a "pure" teaching model. The other tapes revealed instructional methods of an eclectic nature, demonstrating modified and/or combined applications of teaching models and thinking strategies.

When teachers were asked if they felt competent to provide a demonstration of any of the teaching models or strategies, 15 of the 30 respondents reported that they 
did not. The other half (15) of the group indicaced that they felt able to demonstrate one or two of the models or strategies. The frequencies of these responses were the following: cooperative learning model, 7; concept formation model, 5; concept attainment model, 4; concept mapping strategy, 4; problem solving strategy, 3; and advance organizers model, 2 .

All teachers responding to the questionnaire felt that one or more of the teaching models or strategies had become a permanent part of their instructional repertoires. When asked to identify which one(s), the cooperative learning model was most frequently mentioned (15 responses). The concept formation model, concept attainment model, concept mapping strategy, and problem solving strategy were each cited 9 times. The advance organizer model, synectics model, inquiry training model, direct instruction model, and expressive learning strategy each received 2 responses.

Follow-up telephone interviews of a randomly selected subset of 8 teachers not only confirmed responses given on the questionnaire, but provided additional data regarding the use and incorporation of teaching models and strategies into classroom practice. Four of the instructors interviewed indicated that some of the models and strategies presented in the Joint Ventures Program were not new to them. In fact, one teacher remarked that 
he had "always used the Joint Ventures stuff" in his classroom. Another teacher commented, "I had already used inguiry training and advance organizers before Joint Ventures, but now I think I make better decisions about how and when I use them." In addition, three instructors pointed out that they had previously learned about and employed the cooperative learning model in their classrooms.

Summary

The Joint Ventures Program presented seven teaching models and four instructional strategies that teachers may use to promote student thinking. All 30 instructors responding to the study's questionnaire reported having applied and integrated at least one of these models or strategies into their teaching repertoires, the most frequently mentioned being the cooperative learning model. Many teachers also used and incorporated the concept formation and concept attainment models and the concept mapping and problem solving strategies into instructional practices.

The extent to which the models and strategies were used varied according to what teachers deemed appropriate to lesson content and desired outcomes. In addition, most teachers reported that they either modified or combined the instructional models and strategies to suit their teaching styles and the needs of their students. 


\begin{abstract}
CHAPTER V
DISCUSSION, CONCLUSIONS, AND RECOMMENDATIONS
\end{abstract}

INTRODUCTION

The preceding chapter presented research findings based on the analysis of multiple sources of data collected for the purpose of examining the professional growth process of teachers participating in the Joint Venture staff Development Program and determining what effects the program had on instructional decision making and teaching practices. The following discussion includes conclusions and implications drawn from the study's findings. Recommendations are made that will aid educational leaders not only in the evaluation of existing staff development programs, but also in the design and implementation of new programs.

\title{
DISCUSSION
}

Educators generally agree that effective staff development programs are those that effect desired changes in teachers' beliefs, attitudes, and classroom practices (Fullan, 1982; Griffin, 1983; Guskey, 1985). Therefore, if we look at the Joint Ventures Staff Development Program in terms of outcomes, it can be argued that the program 
was effective. As a result of program participation, teachers viewed the instructional process in a new light, evidenced by changes in teachers' approaches to the planning and organization of content and the use of instructional strategies. These changes reflected the belief that teaching thinking is an important part of the instructional process and that, since there are no "blueprints" for good teaching, the role of the teacher as an instructional decision maker is critical to successful learning outcomes of students. Changes in teachers' thinking were accompanied by changes in classroom behavior which included the application and integration of new teaching models and strategies into their instructional repertoires.

Research indicates that effective staff development programs are those which provide a framework for close collegial support (Holly, 1982; Sparks, 1983). The findings of this study strongly support the notion that professional growth best takes place in an interpersonal setting that is supportive and nonthreatening. Teachers in this case enjoyed a learning atmosphere that was interactive and congenial. They valued the mutual respect and sensitivity shown by their peers.

It appears that three major factors were instrumental in promoting this collegial atmosphere: (1) the instructor; (2) the nature of the learning group; 
and (3) interactive learning activities. The instructor encouraged a free and open exchange of ideas during class sessions. He modeled the desired collegial behaviors of teachers through his nonjudgmental acceptance of all responses. Teachers' ideas were not responded to as being either right or wrong but as valuable contributions to the learning at hand. Concerns of the groups and individuals were immediately addressed, and feedback from the group's learning experiences was consistently sought. The instructor experimented with his own teaching, took risks, and acknowledged his mistakes. Through his attitudes and actions, he sent a very clear message to his class, "I am a learner as well as a teacher. We are here to learn and grow together. Your teaching expertise and experience is highly respected and valued as part of our learning process."

The nature of this particular group of teachers also appeared to affect the norm of collegiality that developed. This group consisted of veteran teachers with an average of 15 years of teaching experience. They all attended class with at least one other teacher from their own school. In addition, these individuals were selected to participate in the program because of their instructional leadership qualities. These factors most likely contributed to the interactive, confident class atmosphere. 
Interactive learning activities promoted collegial sharing. Class discussions were an integral part of the learning process. In addition, teachers worked and shared in assigned cooperative learning groups that changed membership from session to session. The peer sharing activity, similar to the Joyce and Showers (1982) peer coaching concept, also provided a framework for teacher support and interaction.

Two other factors that appeared to influence the norm of collegiality less directly were School District support and the planning process utilized by the leadership team. The goals of the program comfortably meshed with the District's philosophy, giving teachers a sense of direction. Although teachers were not involved in the goal-setting process of the program, individuals who were invited to participate had the choice of whether or not to become involved. Those who chose to participate were given release time from their classrooms to do so. In addition, the District showed its support by paying for the nine University credits offered to each participant. Teachers' needs were addressed through the planning process utilized by the leadership team. Initial program planning done by the team resulted in the decision to loosely structure program content and activities and use participant feedback collected after each learning session as a basis for planning subsequent sessions. Because the 
team responded promptly to teachers' suggestions and concerns, participants felt supported and involved in directing the program.

other than the norm of collegiality and support, the teacher training activities employed by the instructor appear to have promoted desired changes in teaching behaviors. Joyce and showers (1980) argue that the most effective inservice training activities are those that combine theory, modeling, practice, feedback, and coaching to application. An instructional pattern that combined these elements was used by the instructor in this case. The modeling done by the instructor seems to have strongly influenced the successful transfer of new learning into classroom practice. The findings of this study indicated that the cooperative learning model was most frequently used and incorporated by teachers into classroom practice. This teaching model was the one most often utilized by the instructor during class sessions. Teachers not only saw the model used on a regular basis, but they also experienced it as learners and found it enhanced their learning. Most likely, teachers felt that if the model increased their learning, it was one that they could successfully use in their classrooms to increase their students' learning.

The successful transfer of new learning into classroom practice that was positively influenced by the 
collegial learning climate and effective training activities also seems to have been promoted by the schedule of class activities during the first two months of the program. During that time the class convened on a biweekly basis. This schedule was effective in that it allowed enough time between sessions for teachers to absorb new material and try it out in their classrooms, but not too much time to elapse so that continuity would be lost. These findings support Sparks' (1983) suggestion that effective inservice workshops are those that are spaced one to two weeks apart to allow teachers to adapt and modify new practices to fit their unique situations. Class scheduling during the middle and latter part of the program seems to have had a negative effect on the transfer of new learning into classroom practice. The findings of this study showed that teachers expressed very little concern about the application of new skills to their classroom practices until the fifth day session of the program, after an eight-week period of time had elapsed between sessions (see Figure 2). At that point in time, well over half of the teachers expressed growing concerns about application. This implies that teachers were beginning to lose continuity after such a long break between sessions. From that point on, sessions continued to be spread out over long time periods. As the program progressed, teachers had more and more ideas to put into 
practice and less time to interact in class and receive feedback on their efforts.

The program appears to have reached a turning point in its effectiveness sometime between the fourth and fifth day sessions not only because program activities became spaced over longer periods of time, but also because the program began to lose the full support of its leadership. During that time the team leader was effectively removed from most of his responsibilities to the program by a series of position changes within the school District. Because he was unavailable to meet with the other members of the leadership team, team planning ceased. Also, the planned follow-up support that was needed by teachers in their classrooms to help them effectively transfer skills was not provided. Originally, the teacher follow-up responsibilities were to be divided between the three members of the leadership team. With one member unavailable, the other two members were unable to carry the load.

The infrequent class meetings along with only two peer sharing activities did not provide teachers with enough feedback and interaction to successfully incorporate much of their newly-learned information into classroom practice during this time of the program. In fact, the evidence shows that very little of what was learned from the fifth session forward was transferred. 
The teaching models and strategies most frequently mentioned by teachers as having been incorporated into their instructional repertoires were all learned during the first four sessions. Since no follow-up support was given in the classrooms at any time during the program, it can be concluded that frequent, ongoing class interaction was the critical factor effecting successful transfer in this case.

Two other factors beyond the scope of this study are likely to have influenced the transfer of skills into classroom practice. One factor is the manner and extent to which each piece of content was taught to teachers. No attempt was made to quantify how much exposure participants had to each of the varied teaching techniques or the time alloted to each piece of content. The second unknown factor affecting transfer in this case was teachers' prior learning and experience in using some of the models and strategies presented in the program. During follow-up phone calls concerning survey results, an unincorporated issue was uncovered. Four of the 8 teachers interviewed had had prior exposure to some of the data presented in class. If these findings are projected onto the whole group of participants, then it can be concluded that at least half of the teachers had been previously exposed to some of the content. Therefore, 
some transfer may have taken place prior to their participation in the program.

This case study examined the professional growth process of teachers participating in the Joint Ventures in Instructional Leadership Program and determined what effect the program had on instructional decision making and teaching practices. Its findings support the large body of research that indicates staff development is a complex process which is influenced by many factors. This study found that when a staff development program is designed and implemented according to guidelines based on current literature as synthesized in the following section of this dissertation, the outcomes of the program will be favorable. This study also found that when program components, such as follow-up support and scheduling needs, are not met, the outcomes will probably be less effective.

\section{RECOMMENDATIONS}

The conclusions and implications from this study lead to the following recommendations that will aid educational leaders not only in the evaluation of existing staff development programs, but also in the design and implementation of new programs.

1. A district staff development specialist or outside consultant should be hired to design and direct a 
district-wide program. The development and implementation of an effective program requires full-time efforts.

2. Staff development goals should comfortably mesh with the school district's goals and philosophy.

3. Clear goals based on assessed needs of teachers must be set for the program. The planning process should be ongoing, and participant feedback should guide program content and activities.

4. Development of teachers' skills in the use of new approaches to teaching and the transfer of them into classroom practice is best achieved through the use of a combination of training components including: study of theory; modeling of skills/strategies; interactive learning activities; practice with feedback; follow-up assistance in the classroom; and extended peer observation activities. All of these components should be included in the design and implementation of professional growth activities.

5. Professional growth best takes place within a norm of collegiality. Staff development activities should promote group interaction and be nonevaluative to help promote a positive learning climate.

6. Teachers must be provided with follow-up assistance in the classroom to insure the successful transfer of skills into teaching practices. 
7. Staff development participants must be given measured doses of content over a period of time that is commensurate with the complexity of program goals and content. The most effective schedule includes workshops that are at least one week, but not more than two weeks apart.

8. The workshop instructor is critical to the success of the program. Workshop instructors should have good teaching skills, demonstrate leadership qualities, and have considerable expertise in the content area to be taught.

\section{SUGGESTIONS FOR FUTURE STUDY}

The preceding conclusions and recommendations regarding the development and implementation of successful staff development programs were developed from a descriptive single-case study. The findings of this study verified several factors identified in the literature review as contributing to the effectiveness of staff development programs. Although this study cannot be replicated, this researcher suggests that additional case studies examining the process of teacher change in other settings be done to further verify or contradict the literature reviewed herein.

A second recommendation for further research would be to examine the long-term effects of professional growth 
programs. This study identified the immediate outcomes of a staff development program. Longitudinal studies are needed to determine what impact staff development practices have on teacher change over a period of time.

A third recommendation for further study would be to investigate the effects that certain individual characteristics of inservice teachers have on the development of a norm of collegiality within their group. The subjects of this study experienced a high level of collegiality apparently influenced by individual characteristics such as age, years of teaching experience, and personality traits. It would be interesting to learn if these and other factors influence the cohesiveness of other groups of inservice participants. Finally, this author suggests that studies be conducted to determine what impact follow-up classroom assistance has on the successful transfer of skills into instructional practices. Future research addressing this issue would be helpful in determining the importance of follow-up assistance as an element of effective staff development programs. 


\section{REFERENCES}

Bents, R. H., and Howey, K. R. (1981). Staff development -Change in the individual. In B. Dillon-Peterson (Ed.), Staff development/Organization development (pp. 11-36). Alexandria, VA: Association for Supervision and Curriculum Development.

Berman, P., \& McLaughlin, M. W. (1976). Implementation of educational innovation. Educational Forum, $40(3)$, 347-370.

Berman, P., \& McLaughlin, M. W. (1978). Federal programs supporting educational change, Vol. VII: Implementing and sustaining innovations. Santa Monica, CA: The Rand Corporation.

Blumer, H. (1966). Sociological analysis and the variable. American Sociological Review, 21, (6), 683-690.

Bogdan, R. C., and Biklen, S. K. (1982). Qualitative research for education: An introduction to theory and methods- Boston, MA: Allyn and Bacon.

Brimm, J.L., \& Tollett, D. J. (1974). How do teachers feel about inservice education? Educational Leadership, $31(6), 521-524$.

Brookover, W., Beady, C., Flood, P., Schweitzer, J., \& Wisenbacker: J. (1979). School social systems and school achievement: Schools can make a difference. New York: Praeger.

Burello, L., \& Orbaugh, T. (1982). Reducing the discrepancy between the known and the unknown in inservice education. Phi Delta Kappan, 63(6). $385-388$.

Casper, P., ano Roecks, A. (1982). Evaluating staff development activities with levels of use interviews, or the sleeper evaluates inservice programs. paper presented at the annual meeting of The American Research Association at New York City. (ERIC Document Reproduction Service No. ED 221 954) 
Crandall, D. P., \& Loucks, S. F. (1982). People, policies, and practices: Examining the chain of school improvement: Vol. X. A roadmap for school improvement. Andover, MA: The NETWORK.

Dillon, B. (1978). A school board member's guide to staff development. Washington, DC: National School Boards Association. (ERIC Document Reproduction Service No. ED 153 324)

Dillon-Peterson, B. (1981). Staff development/ Organization development--Perspective 1981. In B. Dillon-Peterson (Ed.), Staff development/ Organization development (pp. 1-10). Alexandria, VA: Association for Supervision and Curriculum Development.

Edelfelt, R. A. (1975). Introduction. In R. A. Edelfelt and M. Johnson (Eds.), Rethinking in-service education, (pp. 1-23). Washington, DC: National Education Association.

Edmonds, R. (1979). A discussion of the literature and issues related to effective schooling. Social Policy \#9, 6, 28-32.

Edmonds, R. (1982). Programs of school improvement: An overview. Educational Leadership, 40 (3), 4-11.

Fenstermacher, G. D., and Berliner, D. C. (1983). A conceptual framework for the analysis of staff development. A Rand note. Santa Monica, CA: Rand Corporation. (ERIC Document Reproduction Service No. ED 244 906)

Fullan, M. (1982). The meaning of educational change. New York: Teachers College Press.

Fullan, M. \& Pomfret, A. (1977). Research on curriculum and instruction implementation. Review of Educational Research, $47(1), 335-397$.

Gall, M. D., Haisley, F., Baker, R. G., \& Perez, M. (1982). The relationship between inservice education practices and productivity of basic skills instruction. Eugene, OR: University of Oregon, College of Education, Center for Education Policy and Management. (ERIC Document Reproduction Service No. ED 228 745) 
Gall, M. S., and Renchler, R. S. (1985). Effective staff development for teachers: A research-based model. Washington, D.C.: National Institute of. Education. (ERIC Document Reproduction Service No. ED 256 009)

Glaser, B. (1978). Theoretical sensitivity: Advances in the methodology of grounded theory. Mill valley, CA: Sociology Press.

Glaser, B.. \& Strauss, A. (1967). The discovery of grounded theory. Chicago: Aldine Publishing Company, Inc.

Goodlad, J. I. (1975). The dynamics of educational change: Toward responsive schools. New York: McGraw-Hill.

Griffin, G. A. (1982). Staff development. Paper prepared for the NIE Teaching Synthesis Conference. Austin, TX: University of Texas, Research and Development Center for Teacher Education. (ERIC Document Reproduction Service No. ED 221 537)

Griffin, G. A. (1983). Introduction: The work of staff development. In G. A. Griffin (Ed.), Staff development. Eighty-second yearbook of the National Society for the study of Education. Chicago: University of Chicago Press.

Guba, E. (1978). Toward a methodology of naturalistic inguiry in educational evaluation. (Center for the Study of Evaluation Monograph No. 8). Los Angeles: University of California Graduate School of Education.

Guskey, T. R. (1985). Staff development and teacher change. Educational Leadership, 42(7), 57-60.

Hall, G. E., \& Loucks, S. F. (1980) - Program definition and adaptation: Implications for inservice. Austin, TX: Research and Development Center for Teacher Education, University of Texas.

Hall, G. E., Wallace, R. C., \& Dossett, W. A. (1973). A developmental conceptualization of the adoption process within educational institutions. Austin, TX: Research and Development Center for Teacher Education, University of Texas. (ERIC Document Reproduction Service No. ED 095126 ) 
Harootunian, B., \& Yarger, G. P. (1981). Teachers' conceptions of their own success. Washington, DC: ERIC Clearinghouse on Teacher Education. (ERIC Document Reproduction Service No. ED 200 518)

Harris, B. M. (1980). Improving staff performance through inservice education. Boston: Allyn and Bacon.

Harris, B. M., Bessent, W., \& McIntyre, K. E. (1969). Inservice education: A guide to better practice. Englewood Cliffs, NJ: Prentice-Hall.

Hite, H. (1977). Inservice education: Perceptions, purposes, and practices. In Hite and K. R. Howey, Planning inservice teacher education: Promising alternatives. Washington, DC: Eric Clearinghouse on Teacher Education. (ERIC Document Reproduction Service No. ED 183560 )

Holly, M. L. (1982). Teachers' views on inservice training. Phi Delta Kappan, 63(6), 417-418.

Houston, W. R. (1980). The nature of change in schools and universities. In W. R. Houston \& R. Pankratz (Eds.), Staff development and educational change (pp. 4-10) - Reston, VA: Association of Teacher Educators.

Howey, K. R. (1981). The concept of school focused inservice. In K. R. Howey, R. Bents, and D. Corrigan (Eds.), School focused inservice: Descriptions and discussions (pp. 5-23). Reston, VA: Association of Teacher Educators.

Howey, K. R., \& Joyce, B. R. (1978). A data base for future directions in inservice education. Theory into Practice, 27, 206-211.

Howey, K. R., \& Vaughan, J. C. (1983). Current patterns of staff development. In G. A. Griffin (Ed.) Staff Development. Eighty-second yearbook of the National Society for the Study of Education. Chicago: University of Chicago Press.

Issac, S. (1971). Handbook in research and evaluation. San Diego, CA: EDITS Publishers.

Jones, R. M., and Steinbrink, J. E. (1986). Curriculum institutes for teachers: Utilizing local resources. Science Education, 70(2), 105-109. 
Joyce, B. R. (1981). A memorandum for the future. In B. Dillon-Peterson (Ed.), Staff development/ Organization development (pp. 113-127). Alexandria, VA: Association for Supervision and Curriculum Development.

Joyce, B. R., Hersh, R., \& Mckibbin, M. (1983). The structure of school improvement. New York: Longman, Inc.

Joyce, B. R., Howey, K., \& Yarger, S. (1976). I.S.T.E. Report I. Palo Alto, CA: Stanford Center for Research and Development in Teaching.

Joyce, B. R., \& Showers, B. (1980). Improving inservice training: The messages of research. Educational Leadership, 37(5), 379-385.

Joyce, B. R., \& Showers, B. (1981). Teacher training research: Working hypotheses for program design and directions for further study. Paper presented at the meetings of the American Educational Research Association, Los Angeles.

Joyce, B. R., \& Showers, B. (1982). The coaching of teaching. Educational Leadership, $40(1), 4-10$.

Joyce, B. R., and Weil, M. (1986). Models of teaching (3rd ed.). Englewood Cliffs, NJ: Prentice-Hall.

Knowles, M. (1978). The adult learner: A neglected species. Houston, TX: Gulf.

Knox, A. B. (1977) Adult development and learning. San Francisco, CA: Jossey-Bass.

Knox, A. B. (1987). Helping adults learn: A guide to planning, implementing, and conducting programs. San Francisco, CA: Jossey-Bass.

Lawrence, G., Baker, D., Hansen, B., \& Elzie, P. (1974). Patterns of effective inservice education. Tallahassee: Florida Department of Education. (ERIC Document Reproduction Service No. Ed 176 424)

Lawrence, G., \& Harrison, D. (1980). Policy implications of the research on the professional development of education personnel: An analysis of fifty-nine studies. Washington, D.C.: Feistritzer Publications. 
Leithwood, K. A., \& Montgomery, D. J. (1982). The role of the elementary school principal in program improvement. Review of Educational Research, 52 (3), $309-339$.

Lieberman, A. L., \& Miller, L. (1981). Synthesis of research on improving schools. Educational Leadership, 38(7), 583-586.

Little, J. W. (1981). School success and staff development in urban desegregated schools: A summary of recently completed research. Paper presented at the meetings of the American Educational Research Association, Los Angeles.

Locke, W. E. (1985). Teacher attitudes suggest inservice programs. (ERIC Document Reproduction Service No. ED 283785 )

Lortie, D. (1975) - Schoolteacher: A sociological study. Chicago: University of Chicago Press.

Loucks, S., \& Pratt, H. (1979). A concerns-based approach to curriculum change. Educational Leadership, 37(3), 212-215.

Mackenzie, D. (1983). Research for school improvement: An appraisal of some recent trends. Educational Researcher, 12(4), 5-16.

Manasse, A. L. (1985). Improving conditions for principal effectiveness: Policy implications of research. Elementary School Journal, 85(3), 439-463.

McLaughlin, M. W., \& Marsh, D. C. (1978). Staff development and school change. Teachers College Record, 80 (1), 69-93.

Miles, M. B., \& Huberman, A. M. (1984). Focusing and bounding the collection of data. Qualitative data analysis. Beverly Hills, CA: Sage Publications.

Petracek, S. (1986). Inservice training of teachers: Issues and trends. (ERIC Document Reproduction Service No. Ed 287848 )

Prawat, R., \& Anderson, L. (1981). Affect stressed over cognition. IRT Communication Quarterly, 4 (40), (a publication of the Institute for Research on Teaching, Michigan State University). 
Purkey, S., \& Smith, M. (1982). Synthesis of research on effective schools. Educational Leadership, $40(3)$, 64-69.

Rappa, J. B. (1983). Characteristics of successful staff in-service training. Boston, MA: State Department of Education. (ERIC Document Reproduction Service No. ED 243867 )

Rubin, I. (1978). The in-service education of teachers: Trends, processes, and prescriptions. Boston: Allyn and Bacon.

Schatzman, L., \& Strauss, A. (1970). Field research: Strategies for a natural sociology. Englewood Cliffs, NJ: Prentice-Hall.

Schurr, K. T. and Others. (1980). Discrepancies in teacher and administrator preferences for inservice training topics. Paper presented at the annual meeting of the American Educational Research Association, Boston, MA. (ERIC Document Reproduction Service No. ED 186401 )

Showers, B. (1985). Teachers coaching teachers. Educational Leadership, $42(7), 54-56$.

Sparks, G. M. (1983). Synthesis of research on staff development for effective teaching. Educational Leadership, 4l (3), 65-72.

Stallings, J. A., Needels, M., \& Stayrook, N. (1978). How to change the process of teaching basic reading skills in secondary schools: Phase II and phase III final report. Menlo Park, CA: S.R.I. International. (ERIC Document Reproduction Service No. Ed 210 671)

Toch, T. (1982). Inservice efforts fail a system in need, critics say. Education Week, 2(4), 10-11.

Vacca, J. L. (1983). Program implementation. In Staff development leadership: A resource book (pp. $5 \overline{1-58 \text { ). }}$ Columbus, OH: Ohio Department of Education.

Van Cleaf, D. W., \& Reinhartz, J. (1984). Perceivers and non-perceivers: Adaptation through inservice. Clearing House, 40(4), 167-170. 
Walter, J. E. (1984). Staff development in the St. Louis public schools: An inter-organizational analysis. St. Louis, MO: University of Missouri, St. Louis School of Education. (ERIC Document Reproduction Service No. ED 252 962)

Weber, G. (1971). Inner city children can be taught to read: Four successful schools (Occasional paper, No. 18 ). Washington, D.C.: Council for Basic Education.

Willie, R., \& Howey, K. R. (1980). Reflections on adult development: Implications for inservice teacher education. In W. R. Houston \& R. Pankratz (Eds.), Staff development and educational change (pp. 25-52). Reston, VA: Association of Teacher Educators.

Wood, F. H., \& Thompson, S. R. (1980). Guidelines for better staff development. Educational Leadership, $\underline{37}(5), 374-378$.

Wood, F. H., Thompson, S., \& Russell, F. (1981). Designing effective staff development programs. In B. Dillon-Peterson (Ed.), Staff development/ Organization development (pp. 59-91). Alexandria, VA: Association for Supervision and Curriculum Development.

Yin, R. K. (1984). Case study research: Design and methods. Beverly Hills, CA: Sage publications. 
APPENDIX A

SCHEDULE OF JOINT VENTURES STAEF DEVELOPMENT SESSIONS 
Day Sessions

(8:00 a.m. - 3:00 p.m.)

October 7, 1986
Evening Sessions

(7:00 p.m. - 9:00 p.m.)

October 14,1986

October 21, 1986

November 4, 1986

November 18,1986

December 4, 1986

January 13, 1987

February 3, 1987

March 19, 1987*

April 7, 1987

April 30, 1987

* This session was originally planned for March 12. Due to conflicts in Bill Korach's schedule, the meeting was rescheduled for March 19. Because teachers were given short notice of the change, class sessions were offered at two different times that evening (4:30-6:30; 7:009:00) to facilitate attendance. 
APPENDIX B

COVER LETTER AND QUESTIONNAIRE 
November 18,1987

Dear

\author{
During the time we worked together last year in \\ the Joint Ventures program, I began a study to fulfill \\ the dissertation requirement of my doctoral program at \\ Portland State University. The purpose of the study is \\ to describe the staff development process and perceptions \\ of those who participated in the Joint Ventures program. \\ Enclosed is a questionnaire regarding your \\ participation in the program. Please complete the \\ survey and return it to me in the enclosed self-addressed \\ stamped envelope. It would be most helpful to me to \\ receive your response by the first of December. \\ Thank you for your help. I look forward to sharing \\ the findings of this study with you later this year. \\ Sincerely, \\ Christene Jones
}


QUESTIONNAIRE

Please respond to the following questions regarding your participation in the Joint Ventures program. Attached is a description of the concepts/strategies covered in the program that you may wish to refer to while completing the questionnaire.

1. Has your participation in the Joint Ventures program brought about any changes in the way you now make decisions about your teaching (e.g., content, goals, strategies, materials, etc.)?

Yes_ No

2. In the program, you learned about several models of teaching that may be used to promote student thinking (e.g., Taba, Bruner, Gordon, etc.). Have you used any of these models in your classroom? (Exclude the required videotaped lessons and any practice associated with them.)

Yes__ No

If yes, please answer the following questions:

a) Which models have you used?

b) To what extent have your incorporated these models into your classroom teaching?

c) Do you use any of the models differently from the way you learned them?

Yes_ No

If yes, how do you use them differently? 
d) Which of the models used do you feel have become a permanent part of your teaching repertoire?

e) Would you feel competent to demonstrate any of the models now in your classroom?

Yes _ N No

If yes, which ones?

3. In the program, you learned about other teaching strategies that may be used to promote student thinking (e.g., problem solving, concept mapping, etc.). Have you used any of these strategies in your classroom? (Exclude those used in the required videotaped lessons and any practice associasted with them.)

Yes

No

If yes, please answer the following questions:

a) Which strategies have you used?

b) To what extent have you incorporated these strategies into your classroom teaching?

c) Do you use these strategies differently from the way you learned them

Yes No

If yes, how do you use them differently?

d) Which of the strategies used do you feel have become a permanent part of your teaching repertoire? 
e) Would you feel competent to demonstrate any of the strategies now in your classroom?

If

4. Have any unexpected or unplanned things happened to you or your students as the result of your

involvement in the Joint Ventures program?

Yes__ No

If yes, please explain.

5. For what reasons did you choose to participate in the Joint Ventures program?

6. You were asked to participate in the Joint Ventures program because you were seen as an instructional leader or having the potential to become an instructional leader. Please describe your instructional leadership qualities.

7. How many years of teaching experience do you have? (Exclude this year.)

years.

8. At which level did you teach last year?

Elementary $\quad$ Junior High $\quad$ High School
Other (Please describe.)

9. Please indicate the age category to which you belonged last year.

$\begin{array}{rrr}20-24 & 30-34 \\ 25-29 & 35-39\end{array}-^{40-44} \square^{45-49}$


10. Please make comments or share opinions about the Joint Ventures program and your involvement in it in the following space.

You may add your name if you wish. All responses are held strictly confidential. 
APPENDIX C

JOINT VENTURES PROGRAM PARTICIPANTS 
LAKERIDGE HIGH:

1. Marianne Geiger

(Special Ed.)

2. Terry Logan (English

3. Cris Ponti (For. Lang.)

4. Carla Randall (Math.)

5. Ron Severson (Science)

6. Don Swygard (Science)

WALUGA JUNIOR HIGH :

1. Bonnie Hawkins (Science)

2. Amy Meabe (LA/SS)

3. Joan Montague (LA/D.C.)

4. Steve Sherrell (SS/D.C.)

\section{BRYANT ELEMENTARY : \\ 1. Molly Ingle (First) \\ 2. Eileen Vopelak (Fifth)}

HALLINAN ELEMENTARY:

1. Kathy Samsel (P.E.)

2. Barbara Whitaker (Sixth)

RIVER GROVE ELEMENTARY:

1. Pat Pierce (Third)

WESTRIDGE ELEMENTARY :

1. Leanna Jeffords (Sixth)

2. Ned Williams (Fifth

LAKE OSWEGO HIGH:

1. Jeane Bond (English)

2. Jan Brandeburg (Science)

3. Natalia Caribian (English)

4. Mike Goodrich (Science)

5. Rachel Korach (English/ D.C.)

6. Roy Schreiber (Math.) D.C.)
LAKE OSWEGO JUNIOR HIGH:

1. Bob Bowers (Science/

D.C.)

2. Jim Kronser (LA/SS/D.C.)

3. Carl Von Rohr (LA/SS)

4. Jim Wylder (Art)

FOREST HILLS EL EMENTARY :

1. Robert Ellingsen

(Fourth)

2. Bill Vanderheide

(Third)

LAKE GROVE EL EMENTARY:

1. Laura Fribbs (Fourth)

2. Arleen Rice (Sixth)

UPLANDS EL EMENTARY:

1. Sandra Detroit (Sixth)

2. Denise Struck (Second)

TALENTED/GIFTED PROGRAM:

1. Marilyn Hughes

ADMINISTRAT ION :

1. Jean Fairbairn

Westridge Elementary

2. Bill Johnson

Forest Hills

Elementary

3. Sandra Nelson Lakeridge $\mathrm{High}$

4. John Turchi Lake Oswego $\mathrm{High}$

LA - Language Arts

SS - Social Studies

D.C. - Department Chair 
APPENDIX D

JOINT VENTURES PROGRAM OUTLINE 
DAY SESSIONS

Instruction:

Learning

Teaching

Teaching Thinking

Oct ober 7

Learning

Oct ober 21

Learning/Teaching

November 4

Learning/Teaching

November 18

Learning/Teaching
NTGHT SESSIONS

Peer Sharing

Instructional Analysis

Oct ober 14

Peer Sharing

December 4

Peer Sharing
EXTENDED ACTIVITIES

Readings

Lesson Design

Videotaping

Sharing Sessions

Oct ober

Concept Attainment Concept Development

Models of Teaching:

Chapters 2 and 3

\section{Inquiry Training}

Models of Teaching:

Chapter 4

\section{November}

Videotaping

Advance Organizers

Developmental stages

Models of Teaching:

Chapters 5 and 7 
January 13

Teaching Thinking

February

Teaching Thinking

Teaching Thinking
January

Lesson Design

Synect ics

Cooperative Learning

Models of Teaching:

Chapters 10 and

13

February

Videotaping

Lesson Design

Mastery Learning

Teaching Creativity

Models of Teaching:

Chapters 18 and 23

March 19

Instructional Analysis

\section{April}

Selected Readings

Inst ruct i onal

Analysis

April 30

Instructional Analysis

Program Evaluation 
APPENDIX E

JOINT VENTURES PROGRAM CONTENT 


\author{
STAGES OF THEORY \\ 1. acquisition \\ 2. retention \\ 3. retrieval
}

\section{READING COMPREHENSION:} HER BER

1. literal

2. interpretive

3. applied

QUEST ION I NG

1. recall

2. interpretive

3. creative

4. evaluative

\section{TRANSACT IONS}

1. receptive

2. expressive

CONCEPT MAPP ING : VACCA

1. structure

2. relationship

3. hierarchy

4. inclusiveness
HISTORI CAL APPROACHES

TO LEARN ING

1. neurophysiological

2. behavioral

3. cognitive

4. humanistic

LANGUAGE

1. symbolic

2. association

3. attribution

\section{REASONING}

1. inference

2. inductive

3. deduct ive

4. analogical

5. dialectical

\section{CRITICAL ELEMENTS}

OF LEARN ING

1. memory

2. transfer
TEACHING CONCEPTS:

TERM I NOLOGY

1. concept

2. attribute

3. categorization

4. attribute value

5. essential

attribute

6. nonessential attribute

7. exemplar

8. generalization

COGNITIVE DI STINCTIONS

1. thought

2. thinking

3. thinking skills

COGNITIVE LEVELS:

BLOOM

1. knowledge

2. comprehension

3. application

4. analysis

5. synthesis

6. evaluation 
DEVELOPMENTAL STAGES

1. cognitive/Piaget

2. moral/Kohlberg

3. brain/Epstein

\section{TEACH ING THINKING}

1. differentiating

2. distancing

3. creating

FIVE ELEMENTS OF A CONCEPT: BRUNER

1. name

2. examples

3. attributes

4. attribute values

5. rule

\section{COGNITIVE SHARING}

1. design options

2. decision

opportunities

\section{PROBLEM SOLVING}

1. identify problem

2. represent problem

3. transfer knowledge

4. construct hypothes is

5. exper iment

6. evaluate

PERSPECT IVES ON TEACH ING

1. art

2. science

\section{TEACHER ROLES}

1. instruction

2. management

3. leadership

\section{PERCEPT ION}

1. habituation

2. visual ambiguity

3. past perception

4. reduction
APPROACHES TO THINKING

1. cognitive

processes

2. heuristics

3. stage development

4. language and symbol

5. thinking as subject

\section{COGNITIVE TERMINOLOGY}

1. cognitive

2. metacognitive

3. schema

4. cognitive

$$
\text { structure }
$$

5. cognitive belief system

6. conceptual ecology

7. propositions

8. productions

9. images 
MODELS OF TEACHING

1. Concept formation (Taba)

2. Concept attainment (Bruner)

3. Inquiry training (Suchman)

4. Advance organizers (Ausubel)

5. Direct instruction (Rosenshine)

6. Synectics (Gordon)

8. Cooperative learning (Johnson)
SAMPLE PROGRAM TO TEACH THINKING:

PROJECT INTELLIGENCE

1. Foundations of Reasoning

2. Understanding Language

3. Verbal Reasoning

4. Problem Solving

5. Decision Making

6. Inventive Thinking 